\title{
Interaction of Compliance and Voluntary Renewable Energy Markets
}

Technical Report NREL/ TP-670-42096

October 2007

Lori Bird and Elizabeth Lokey

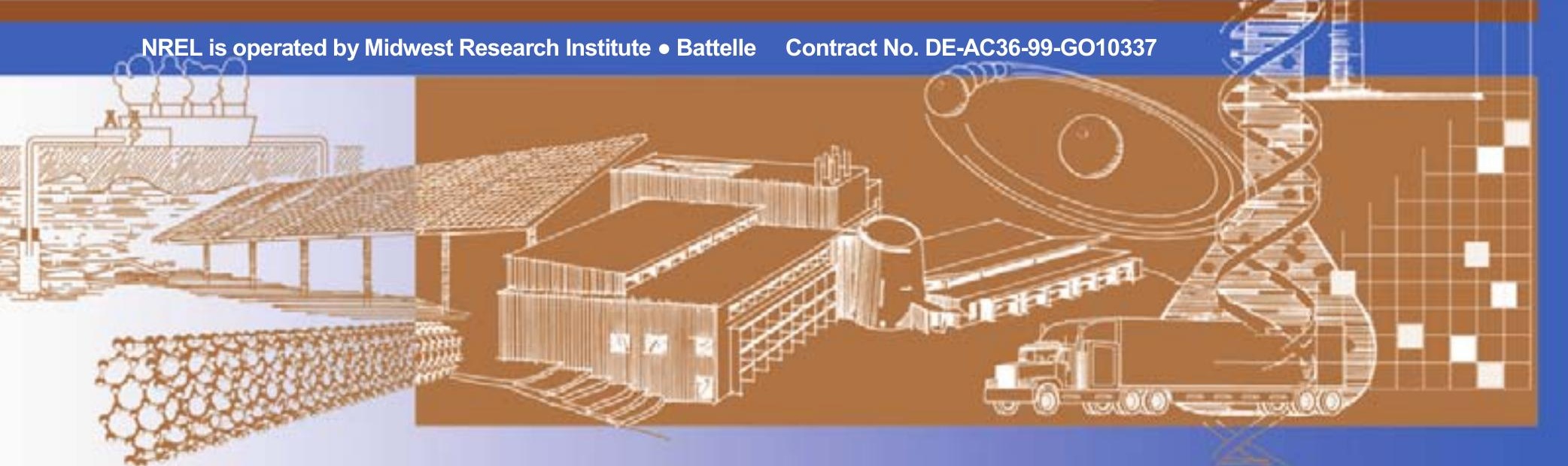




\section{Interaction of Compliance and Voluntary Renewable Energy Markets}

\section{Lori Bird and Elizabeth Lokey}

Prepared under Task No. IGST.7330

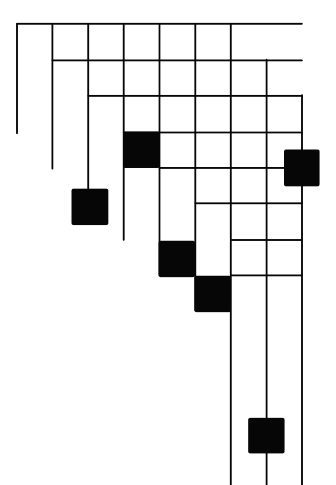




\section{NOTICE}

This report was prepared as an account of work sponsored by an agency of the United States government. Neither the United States government nor any agency thereof, nor any of their employees, makes any warranty, express or implied, or assumes any legal liability or responsibility for the accuracy, completeness, or usefulness of any information, apparatus, product, or process disclosed, or represents that its use would not infringe privately owned rights. Reference herein to any specific commercial product, process, or service by trade name, trademark, manufacturer, or otherwise does not necessarily constitute or imply its endorsement, recommendation, or favoring by the United States government or any agency thereof. The views and opinions of authors expressed herein do not necessarily state or reflect those of the United States government or any agency thereof.

Available electronically at http://www.osti.gov/bridge

Available for a processing fee to U.S. Department of Energy and its contractors, in paper, from:

U.S. Department of Energy

Office of Scientific and Technical Information

P.O. Box 62

Oak Ridge, TN 37831-0062

phone: 865.576 .8401

fax: 865.576 .5728

email: mailto:reports@adonis.osti.gov

Available for sale to the public, in paper, from:

U.S. Department of Commerce

National Technical Information Service

5285 Port Royal Road

Springfield, VA 22161

phone: 800.553.6847

fax: 703.605.6900

email: orders@ntis.fedworld.gov

online ordering: http://www.ntis.gov/ordering.htm 


\section{Acknowledgments}

This work was funded by the U.S. Department of Energy's (DOE) Office of Energy Efficiency and Renewable Energy (EERE). The authors wish to thank Linda Silverman and John Atcheson and the EERE renewable energy technology programs for their support of this work. The authors also wish to thank the following individuals for providing thoughtful review comments: Karlynn Cory, David Hurlbut, and Blair Swezey of NREL; Jeff Anthony and Elizabeth Salerno of the American Wind Energy Association; Ed Holt of Ed Holt \& Associates, Inc.; Kevin Porter of Exeter Associates, Inc.; Tom Rawls of THR Associates, LLC; and Jan Hamrin of the Center for Resource Solutions. The authors also wish to thank Jennifer Josey and Michelle Kubik of the National Renewable Energy Laboratory (NREL) for editorial support. 


\section{Table of Contents}

List of Figures.............................................................................................................................v

List of Tables ...............................................................................................................................

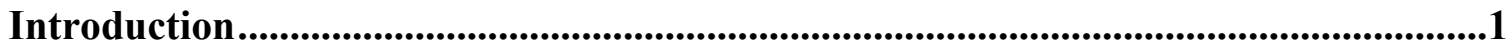

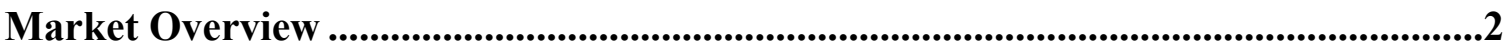

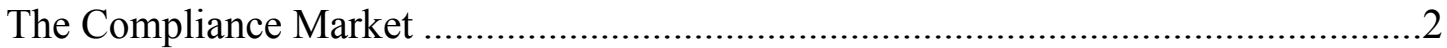

The Voluntary Renewable Energy Market ………………...........................................5

Market Interaction Experience and Issues......................................................................7

Market Additionality and Double Counting .............................................................

Role of Tracking Systems in Addressing Double Counting....................................8

Treatment of Voluntary Purchases in RPS Rules ..................................................

Third-Party Certification of Products in Voluntary Markets...................................12

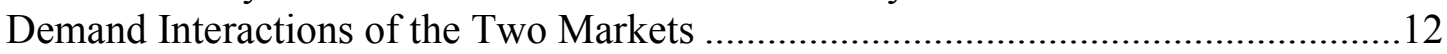

Complementary Timing and Demand................................................................13

Support for Technology and Geographic Diversity ............................................14

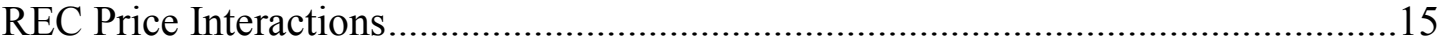

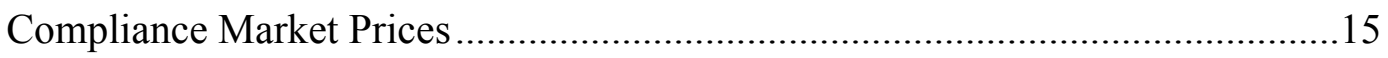

Voluntary Market Prices .......................................................................................16

Relationship Between RPS and Voluntary Market Participation..................................18

Voluntary Market Influence on RPS Adoption ....................................................18

RPS Influence on Voluntary Market Participation ...............................................19

Summary and Conclusions ...............................................................................................21

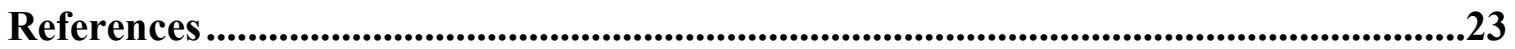




\section{List of Figures}

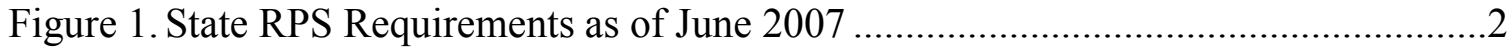

Figure 2. Map of Green Power Providers in U.S .........................................................6

Figure 3. Historical and Projected Voluntary and Compliance Market Growth................. 7

Figure 4. Map of Regional Tracking Systems............................................................. 9

Figure 5. Compliance REC Market Prices ........................................................................16

Figure 6. Voluntary and Compliance REC Prices for the PJM Region, \$/MWh..............17

Figure 7. Voluntary Green Power Sales in Selected States with RPS .............................19

Figure 8. Voluntary Green Power Purchases through Utility Programs in States with

RPS

\section{List of Tables}

Table 1. Detailed Description of RPS Requirements....................................................4

Table 2. States that Require Electricity Providers to Offer Green Power Options .............5

Table 3. State Treatment of Voluntary Purchases in RPS Compliance ............................11

Table 4. 2006 Wholesale/Large Commercial Voluntary REC Prices (New

Renewables) 


\section{Introduction}

In recent years, both compliance and voluntary markets have emerged to help support the development of renewable energy resources. ${ }^{\mathrm{a}}$ Compliance markets are primarily driven by state renewable portfolio standards (RPS), which require utilities or other load serving entities to procure renewable energy for a portion of their electricity supplies. Voluntary markets differ in that they provide consumers with the option to purchase or support renewable energy for a portion or all of their electricity needs. We refer to this as the voluntary market or the "green power market" because these renewable energy purchases are made on a voluntary basis, driven largely by an interest in using cleaner and more sustainable sources of electricity.

Both of these markets are growing rapidly. Today, about half of U.S. states have RPS policies in place, with a number of these policies adopted in the last several years. In addition, many states have recently increased the stringency of their RPS policies. For example, Colorado expanded from a 10\% renewable energy target to a $20 \%$ target in March 2007. And a national RPS is being debated in Congress. Voluntary markets are also growing rapidly, driven largely by interest on the part of large corporations and institutional customers. In fact, renewable energy sales in voluntary markets have grown at rates ranging from $40 \%$ to $60 \%$ annually for the past several years. Collectively, the compliance and voluntary renewable energy markets made up an estimated $1.7 \%$ of total U.S. electric power sales in $2006 .^{1}$

As these markets evolve and grow, a number of issues arise with respect to their interplay. For example, how do these two markets interact in terms of providing demand for renewable energy and supporting new renewable energy development? Are these markets complementary? Do voluntary consumer purchases support renewable energy beyond those supported by renewable energy mandates? Do the markets support different technologies or renewable energy development in different regions of the country? How does demand from the two markets impact prices? And, finally, as the number and stringency of RPS policies increases, is there a need for voluntary markets and will consumers continue to be interested in making voluntary purchases?

This paper examines key market interaction issues between compliance and voluntary renewable energy markets. First, it provides an overview of both the compliance and voluntary markets, addressing each market's history, purpose, size, scope, and benefits. The next section discusses the issue of whether consumer purchases of renewable energy are above and beyond mandated requirements and measures that are in place to avoid double counting. The following sections focus on supply and demand issues and the impact on renewable energy certificate (REC) prices resulting from the two markets. Finally, the paper examines the question of whether consumers will maintain interest in making voluntary purchases if RPS policies are in place.

\footnotetext{
${ }^{a}$ In addition, utilities may also enter into contracts for renewable energy generation that is deemed cost competitive under the Integrated Resource Planning (IRP) process or otherwise, but we do not focus on renewable energy obtained through IRP processes here.
} 


\section{Market Overview}

\section{The Compliance Market}

As of September 2007, 25 states and the District of Columbia had adopted renewable portfolio standards (RPSs) while several other states-including Missouri, Vermont, and Virginia-have nonbinding renewable energy goals (see Figure 1 for a map of states with RPS requirements and goals). Iowa was the first state to require electricity providers to purchase a minimum amount of renewable energy in 1983. Minnesota followed suit in 1994, and California began discussing the idea in 1995. Since then, half of U.S. states have adopted RPS policies through legislation, regulatory channels, and voter-approved ballot initiatives (Washington and Colorado) (see Table 1). In the past three years, there has been significant momentum for state RPS policies with more than 10 states adopting legislation and about 15 increasing their requirements. ${ }^{2}$ The Union of Concerned Scientists estimates that these state renewable energy standards, if fully met, will require more than $67,000 \mathrm{MW}$ of existing and new renewable energy capacity in $2020 .^{3}$

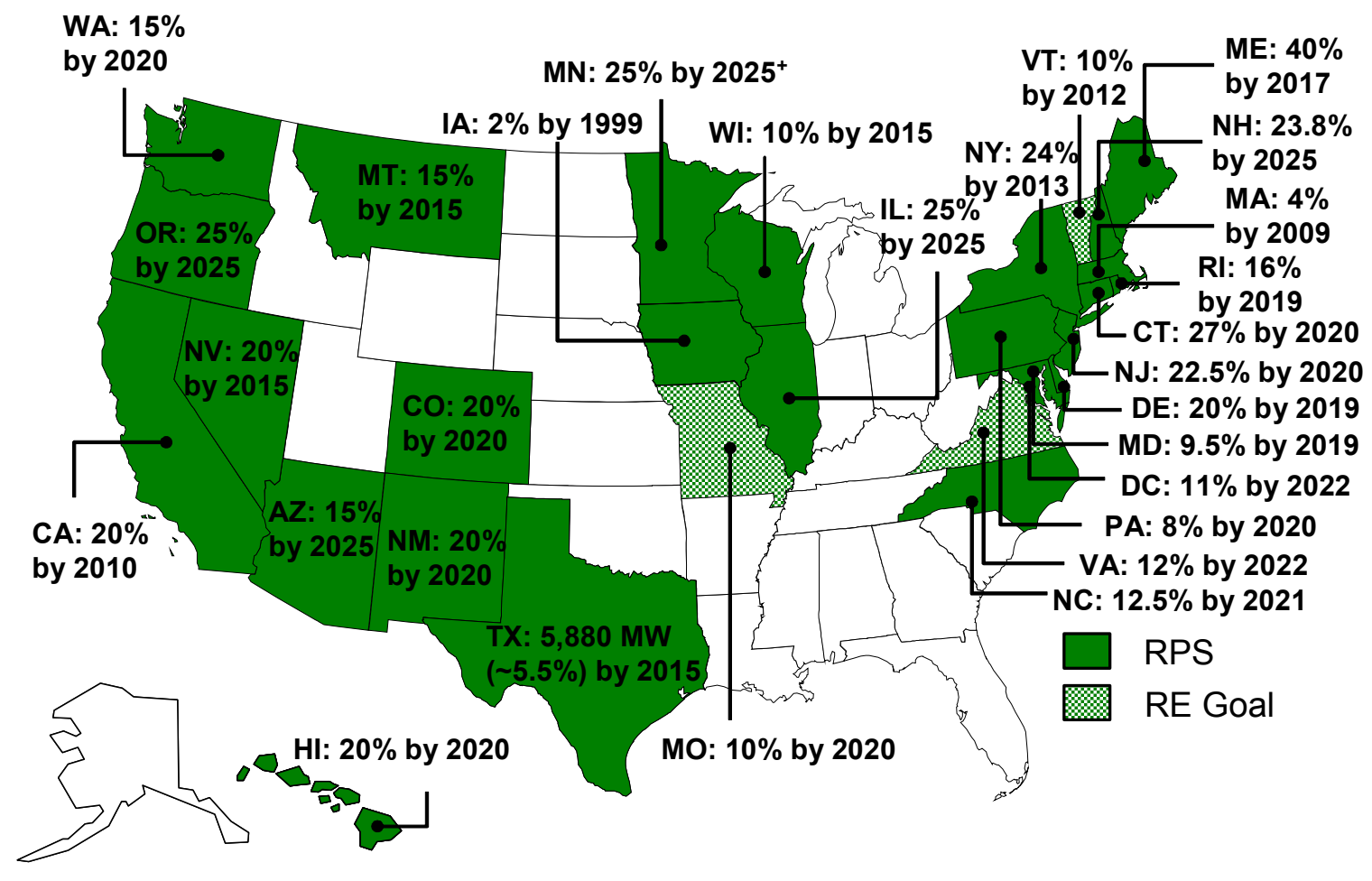

Figure 1. State RPS Requirements as of June 2007

Source: Updated by NREL from original map by Union of Concerned Scientists.

States have adopted RPS policies for a variety of reasons, including diversification of energy sources, reduction of natural gas demand, new job creation, and environmental benefits. ${ }^{4}$ This particular policy instrument is advantageous because, if properly implemented, it provides market demand for renewable technologies and will lead to a predetermined amount of renewable energy generation by an established date. In addition, it contains market-based elements that encourage the implementation of the 
least-cost form of renewable generation necessary to meet the standard. In some cases, states have also established set-asides or specific targets to encourage particular technologies, such as solar. For example, New Jersey requires $2.12 \%$ of its $22.5 \%$ RPS requirement to be derived from solar resources. ${ }^{5}$

The explicit stated purpose of an RPS varies from state to state. States like Colorado have broad goals such as "improv[ing] the natural environment of the state" while others like New York specifically affirm that the RPS is "expected to result in the displacement of some existing fossil fuel-based generation supply" and "reduce air emissions and other adverse environmental impacts." Whether or not an RPS actually produces these benefits depends on how it is structured, the eligible resources, and whether it has noncompliance penalties. The RPS in Maine has not promoted new renewable development because the renewable generation target was initially set at $30 \%$, and the state already derived $50 \%$ of its electricity from renewable sources when the RPS was passed in 2000. Note that a new state law in Maine adopted in 2007 is expected to lead to new renewable energy development going forward because it includes a new renewable energy capacity requirement of $10 \%$ by $2017 .{ }^{7}$ On the other hand, the Texas RPS has prompted the development of more than 3,900 MW of new renewable energy capacity since first adopted in $2002 .{ }^{8}$

To track compliance, many states allow for the use of renewable energy certificates (RECs), which capture the value of the non-electricity attributes of renewable energy. These certificates allow renewable energy generation to be tracked separately from the electrons that can be sold under separate energy contracts or into the energy spot market. For example, Texas was one of the first states to develop a REC tracking system for its RPS, in accordance with the initial RPS legislation (Senate Bill 7). ${ }^{9}$ Today, most states use RECs for RPS compliance. States that choose not to recognize RECs as a valid method of RPS compliance instead use contracts for electricity, which specify that the generation and attributes of generation are sold together, or bundled. ${ }^{10}$ 
Table 1. Detailed Description of RPS Requirements

\begin{tabular}{|c|c|c|c|}
\hline State & Requirement & $\begin{array}{l}\text { Date Adopted } \\
\text { (Revisions) }\end{array}$ & Comments \\
\hline$A Z$ & $\begin{array}{l}1.25 \% \text { in } 2006 ; 2 \% \text { in } 2009 ; 5 \% \text { in } 2015 ; 15 \% \text { in } \\
2025\end{array}$ & $\begin{array}{l}1996 \\
(2001)\end{array}$ & $\begin{array}{l}\text { Applies to all utilities; RECs may be purchased to fulfill need; costs of } \\
\text { program recovered through increased rate base; credit multipliers for } \\
\text { in-state generation and installation; noncompliance fees can be } \\
\text { assessed }\end{array}$ \\
\hline $\mathrm{CA}$ & $\begin{array}{l}\text { Utilities increase total RE sales by } \\
\text { minimum } 1 \% \text { annually to } 20 \% \text { by } 2010\end{array}$ & 2002 & $\begin{array}{l}\text { Applies to } 3 \text { largest IOUs and direct access service provider in '06; } \\
\text { above-market cost of renewables paid for out of system benefit fund. }\end{array}$ \\
\hline $\mathrm{CO}$ & $\begin{array}{l}3 \% \text { in } 2007,5 \% \text { in } 2008-2010,10 \% \text { in } 2011- \\
2014,15 \% \text { in } 2015-2019,20 \% \text { in } 2020 \text {, solar set } \\
\text { aside of } 4 \% \text { of the required amount }\end{array}$ & $\begin{array}{l}2004 \\
(2006)\end{array}$ & $\begin{array}{l}\text { Small rural electrics, cooperatives (coops), and municipalities } \\
\text { (munis) meet half of requirement; multiplier for in-state and } \\
\text { community-based generation; rate impact of } 2 \% \text { for residential IOU } \\
\text { customers and } 1 \% \text { for rural electric; penalties for noncompliance }\end{array}$ \\
\hline CT & $\begin{array}{l}\text { By 2020: Class I technologies*: } 20 \% \text {; Class I or } \\
\text { II 3\%; Class III } 4 \%\end{array}$ & $\begin{array}{l}1998 \\
(2004) \\
\end{array}$ & $\begin{array}{l}\text { Applies to IOUs only; noncompliance fee of } 5.5 \phi \text { per kWh; utilities } \\
\text { must contract for } 100 \mathrm{MW} \text { of new in-state generation }\end{array}$ \\
\hline D.C. & $\begin{array}{l}\text { Tier } 1 \text { Renewables: } 1.5 \% \text { in } \\
2007,7.5 \% \text { in } 2019,8.5 \% \text { in } 2020,9.5 \% \text { in } \\
2021 \text {, and } 11 \% \text { in } 2022\end{array}$ & 2005 & $\begin{array}{l}\text { Applies to all retail sales from competitive electric providers; munis } \\
\text { and rural electrics can exempt themselves if they offer green power } \\
\text { pricing program; only } 1 \% \text { of requirements met by existing resources;; } \\
\text { credit multipliers for solar, fuel cells, and in-state wind }\end{array}$ \\
\hline $\mathrm{HI}$ & $\begin{array}{l}7 \% \text { in } 2003 ; 8 \% \text { in } 2005-2009 ; 10 \% \text { in } 2010- \\
2014 ; 15 \% \text { in } 2015-2019 ; 20 \% \text { in } 2020\end{array}$ & $\begin{array}{l}2005 \\
(2006) \\
\end{array}$ & $\begin{array}{l}\text { Applies to all utility sales; utilities may aggregate renewable } \\
\text { purchases to fulfill mandate; applies to new and old renewables }\end{array}$ \\
\hline IA & $\begin{array}{l}105 \text { average MW, approximately } 2 \% \text { of } 1999 \\
\text { sales }\end{array}$ & $\begin{array}{l}1983(1991) \\
(2003)\end{array}$ & Applies to IOUs only; IOUs can own generation that meets standard \\
\hline $\mathrm{IL}$ & $10 \%$ by $2015 ; 25 \%$ by 2025 & 2007 & $\begin{array}{l}\text { Previous state goal existed; does not cover alternative retail } \\
\text { electricity suppliers,; } 75 \% \text { must come from wind and local RE }\end{array}$ \\
\hline MA & $4 \%$ from new generation by 2009 & 1997 & $\begin{array}{l}\text { Applies to IOUs only; Alternative Compliance Payment (ACP) of } 5 \\
\phi / k W h \text {. }\end{array}$ \\
\hline ME & $30 \%$ in $2000 ; 10 \%$ new generation by 2017 & $1997(2006)$ & $\begin{array}{l}\text { Existing renewables qualify for } 30 \% \text {; new generation does not } \\
\text { include MSW }\end{array}$ \\
\hline MD & $\begin{array}{l}\text { Tier } 1^{*} \text { and Solar: } 9.5 \% \text { in } 2019 . \text { Tier } 2: 2.5 \% \\
\text { through } 2018 .\end{array}$ & 2004 & $\begin{array}{l}\text { Applies to all utilities except major industrial customers who can opt } \\
\text { out; solar makes up } 2 \% \text { of } 9.5 \% \text {; ACP set }\end{array}$ \\
\hline $\mathrm{MN}$ & $\begin{array}{l}1 \% \text { in } 2005 ; 7 \% \text { in } 2010 ; 12 \% \text { in } 2012 ; 17 \% \text { in } \\
2016 ; 20 \% \text { in } 2020 ; 25 \% \text { in } 2025 ; \text { Xcel Energy } \\
\text { requirement } 30 \% \text { by } 2025\end{array}$ & $\begin{array}{l}1994(1997) \\
(2003)(2007)\end{array}$ & $\begin{array}{l}\text { Of Xcel's } 30 \%, 25 \% \text { must be from wind. REC trading must be in } \\
\text { place by January } 2008 \text {. PUC may order a utility to build a renewable } \\
\text { energy facility, buy renewable power or RECs, or other activities if it } \\
\text { is not in compliance. }\end{array}$ \\
\hline NC & $12.5 \%$ by 2021 & 2007 & $\begin{array}{l}40 \% \text { of RPS met with efficiency; net metering/interconnection rules } \\
\text { simplified }\end{array}$ \\
\hline $\mathrm{NH}$ & $23.8 \%$ by $2025 ; 16.3 \%$ of goal must be new RE & 2007 & 4 tiers of technologies with separate goals; RE must be in NEPOOL \\
\hline NJ & $\begin{array}{l}\text { Class I or II Technologies*: } 2.5 \% \text { by } 2004-2020 . \\
\text { Class I: } 0.74 \% \text { in } 2004 \text { and } 17.88 \% \text { in } 2020 .\end{array}$ & $\begin{array}{l}1999 \\
(2006)\end{array}$ & $\begin{array}{l}\text { Applies to all retail and basic providers; ACPs established; } \\
\text { renewables implemented through the NJ Societal Benefits Charge } \\
\text { can meet RPS; includes solar set-aside of } 2.12 \% \text { by } 2020\end{array}$ \\
\hline NM & $\begin{array}{l}5 \% \text { of retail sales in } 2006,10 \% \text { in } 2011,15 \% \text { in } \\
2015 \text {, and } 20 \% \text { in } 2020\end{array}$ & $\begin{array}{l}2000 \\
(2002)\end{array}$ & $\begin{array}{l}\text { Rural electrics meet half of requirement; credit multipliers for wind } \\
\text { and solar; only RECs for generation delivered in NM accepted; caps } \\
\text { on rate impact }\end{array}$ \\
\hline NV & $\begin{array}{l}6 \% \text { of retail electricity sales for } 2005-2006 \text {, } \\
\text { growing to } 9 \% \text { for } 2007-2008,12 \% \text { in } 2009- \\
2010,15 \% \text { for } 2011-2012,18 \% \text { for } 2013- \\
2014 \text {, and } 20 \% \text { in } 2015 \text {. }\end{array}$ & $\begin{array}{l}1997 \\
(2005)\end{array}$ & $\begin{array}{l}\text { Only applies to retail electric suppliers (not munis and coops); } 5 \% \text { of } \\
\text { total renewable power must come from solar resources; credit } \\
\text { multipliers for on-site RE and energy efficiency; energy efficiency can } \\
\text { only meet } 25 \% \text { of requirement and } 50 \% \text { of it must be on-site at } \\
\text { residential customers }\end{array}$ \\
\hline NY & $\begin{array}{l}\text { New RE requirement: } 0.8 \% \text { in } 2006 \text { and } \\
6.56 \% \text { in } 2013 \text {. State purchases must be } \\
19.45 \% \text { in } 2003 \text { and } 24 \% \text { in } 2013 \text {. }\end{array}$ & 2004 & $\begin{array}{l}\text { Applies to IOUs only; customer-sited RE must be } 2 \% \text { of total } \\
\text { requirements; } 1 \% \text { additional RE purchases must come from } \\
\text { voluntary market; RE must be delivered into NY; only RE generators } \\
\text { built after } 1 / 1 / 03 \text {; rate impact set }\end{array}$ \\
\hline OR & $\begin{array}{l}25 \%, 10 \%, 5 \% \text { for large, medium, and small } \\
\text { utilities by } 2025\end{array}$ & 2007 & $\begin{array}{l}\text { Goal of } 8 \% \text { retail load from RE projects under } 20 \mathrm{MW} ; \mathrm{ACP} \\
\text { established; generation must come from sources built after January } \\
1,1995\end{array}$ \\
\hline PA & $\begin{array}{l}\text { Tier I technologies }{ }^{*} 1.5 \% \text { by } 2007,2 \% \text { by } 2008 \text {, } \\
\text { and } 8 \% \text { by } 2020 ; \text { Tier II technologies: } 4.2 \% \text { by } \\
2009,6.2 \% \text { by } 2014,8.2 \% \text { by } 2019 \text {, and } 10 \% \text { in } \\
2020 \text {. }\end{array}$ & $\begin{array}{l}1998 \\
(2004)\end{array}$ & $\begin{array}{l}\text { Applies to IOUs only; rural electrics must offer energy efficiency } \\
\text { program to customers; solar set-aside of } .5 \% \text { by } 2020 \text {; allows for } \\
\text { utility cost recovery; establishes ACP }\end{array}$ \\
\hline $\mathrm{RI}$ & $\begin{array}{l}3 \% \text { by } 2007,4.5 \% \text { by } 2010,8.5 \% \text { by } 2014 \text {, and } \\
16 \% \text { by } 2019 .\end{array}$ & 2004 & $\begin{array}{l}\text { No more than } 2 \% \text { of each year's requirement can be met with } \\
\text { existing (pre-1998) renewables; establishes an ACP; RE must be } \\
\text { delivered into NEPOOL. }\end{array}$ \\
\hline $\mathrm{TX}$ & $\begin{array}{l}1280 \text { MW by } 2003 ; 1730 \text { MW by } 2005 ; 2280 \\
\text { MW by } 2007 ; 3272 \text { MW by } 2009 ; 4264 \text { MW by } \\
2011 ; 5256 \text { MW by } 2013 ; 5880 \text { MW by } 2015\end{array}$ & $\begin{array}{l}1999 \\
(2005)\end{array}$ & $\begin{array}{l}\text { Munis and coops subject to RPS if they opt into retail competition; } \\
\text { out-of-state generation not allowed unless there is a transmission } \\
\text { line; ACP set }\end{array}$ \\
\hline WA & $\begin{array}{l}3 \% \text { of total delivered retail electric load in } 2012 \text {, } \\
9 \% \text { in } 2016, \text { and } 15 \% \text { in } 2020 .\end{array}$ & 2006 & $\begin{array}{l}\text { All utilities included; RE must be built after 3/31/99; facilities must be } \\
\text { in WA or deliver into PNW; ACP set }\end{array}$ \\
\hline WI & $\begin{array}{l}\text { Goal } 10 \% \text { by } 2015 ; 2 \% \text { above utility avg. by } \\
2010 ; 6 \% \text { above avg. } 2015\end{array}$ & $\begin{array}{l}1999 \\
(2006)\end{array}$ & $\begin{array}{l}\text { Applies to all utilities. Requirements based on utility's average } \\
\text { percentage of renewable energy generation in } 2001-2003 \text {. }\end{array}$ \\
\hline
\end{tabular}

${ }^{*}$ Class or Tier I technologies usually refer to new renewables while other tiers refer to existing or cost-competitive renewables. 


\section{The Voluntary Renewable Energy Market}

In contrast to compliance markets, the voluntary market enables customers to choose to purchase renewable energy equivalent to a portion or all of their own electricity consumption. Today, more than $50 \%$ of U.S. electricity consumers have the option to purchase renewable energy through their utility or electricity provider, generally at a premium above standard electricity rates. ${ }^{b}$ In states with restructured electricity markets, customers can choose to switch electricity providers if their current provider does not offer a green energy option. In addition, all customers have the option to purchase RECs separate from electricity through a local or national REC marketer. Generally, these options provide consumers with the ability to purchase renewable energy without the upfront capital costs typically associated with on-site renewable energy systems. Some states require utilities to offer green power options to consumers (see Table 2).

Table 2. States that Require Electricity Providers to Offer Green Power Options

\begin{tabular}{|c|c|c|}
\hline State & Adoption & Requirement \\
\hline $\mathrm{CO}$ & Mar 2007 & $\begin{array}{l}\text { Municipal utilities to offer an optional pricing program allowing retail } \\
\text { customers to support emerging renewable energy technologies }\end{array}$ \\
\hline CT & June 2003 & $\begin{array}{l}\text { Default suppliers required to offer green power options in conjunction with } \\
\text { marketers }\end{array}$ \\
\hline IA & June 2001 & All utilities required to offer green power pricing programs \\
\hline $\mathrm{MN}$ & June 2001 & $\begin{array}{l}\text { Utilities required to offer renewable energy or low-emitting energy sources } \\
\text { to customers }\end{array}$ \\
\hline MT & May 2003 & $\begin{array}{l}\text { Default electricity service providers to offer green power options to their } \\
\text { retail customers }\end{array}$ \\
\hline NJ & May 2003 & $\begin{array}{l}\text { Default suppliers required to offer green power options in conjunction with } \\
\text { marketers }\end{array}$ \\
\hline NM & Dec 2002 & $\begin{array}{l}\text { Utilities required to offer green tariff for renewable energy to customers and } \\
\text { educate about program }\end{array}$ \\
\hline OR & $\begin{array}{l}\text { Jan } 2002 ; \\
\text { June } 2007\end{array}$ & $\begin{array}{l}\text { Investor-owned utilities required to offer renewable energy options to } \\
\text { residential and small commercial customers; all utilities in state required to } \\
\text { offer green power options }\end{array}$ \\
\hline VA & June 2003 & Customers to have a $100 \%$ renewable energy purchase option \\
\hline WA & Jan 2006 & $\begin{array}{l}\text { Utilities serving more than } 25,000 \text { meters required to offer green power } \\
\text { option to customers }\end{array}$ \\
\hline
\end{tabular}

Customers make the decision to pay a premium for renewable energy for a variety of reasons including: environmental quality, resource diversity, energy security, job creation, and industry development. Many consumers are interested in supporting the development of renewable energy beyond what is supported by policies and regulation. Often customers see their purchases as displacing carbon emissions that occur through

\footnotetext{
${ }^{\mathrm{b}}$ In some instances green power customers may not pay a premium for their green power. Some utilities offer a waiver of the fuel cost adjustment for their consumers that purchase green power. When natural gas prices are high, this waiver can mean that green energy customers save money. This was the case for Xcel Windsource customers in Colorado during the winter of '05-'06 (Steve Raabe, "Steady Wind Means Pricier Power," Denver Post, Business, August 7, 2006).
} 
conventional energy generation because green power marketers advertise the purchase as such. ${ }^{11}$ For example, the Bonneville Environmental Foundation (BEF) claims that "Using clean renewable energy is friendly to the environment and reduces emissions of carbon dioxide and other greenhouse gases. Green Tags represent the real savings in carbon dioxide and other pollutants that occur when green power replaces burning fossil fuel." BEF, like a number of other marketers, also includes a carbon calculator on their Web page that allows customers to calculate their emissions and equivalent offsets. ${ }^{12}$

Today, more than 750 utilities and marketers offer green power products to electricity consumers in most states (see Figure 2). In addition, a number of companies offer REC products separate from electricity. In 2005, consumers made voluntary purchases of renewable energy totaling about 8.5 million MWh and 2006 purchases are estimated to total about 12 million MWh. The voluntary market grew by $62 \%$ in $2004,37 \%$ in 2005 , and $40 \%$ in $2006 .{ }^{13}$ Currently, the voluntary market represents nearly one-fifth of the overall renewable energy demand from both compliance and voluntary markets on a MWh-basis. If the voluntary market continues to grow at a rate of $35 \%$ annually, it will reach about 40 million MWh by 2010 and represent about one-quarter of the total demand from voluntary and compliance markets (see Figure 3). Voluntary markets would represent a larger fraction of the total if we considered only the new renewable energy generation that is required to meet RPS policies.

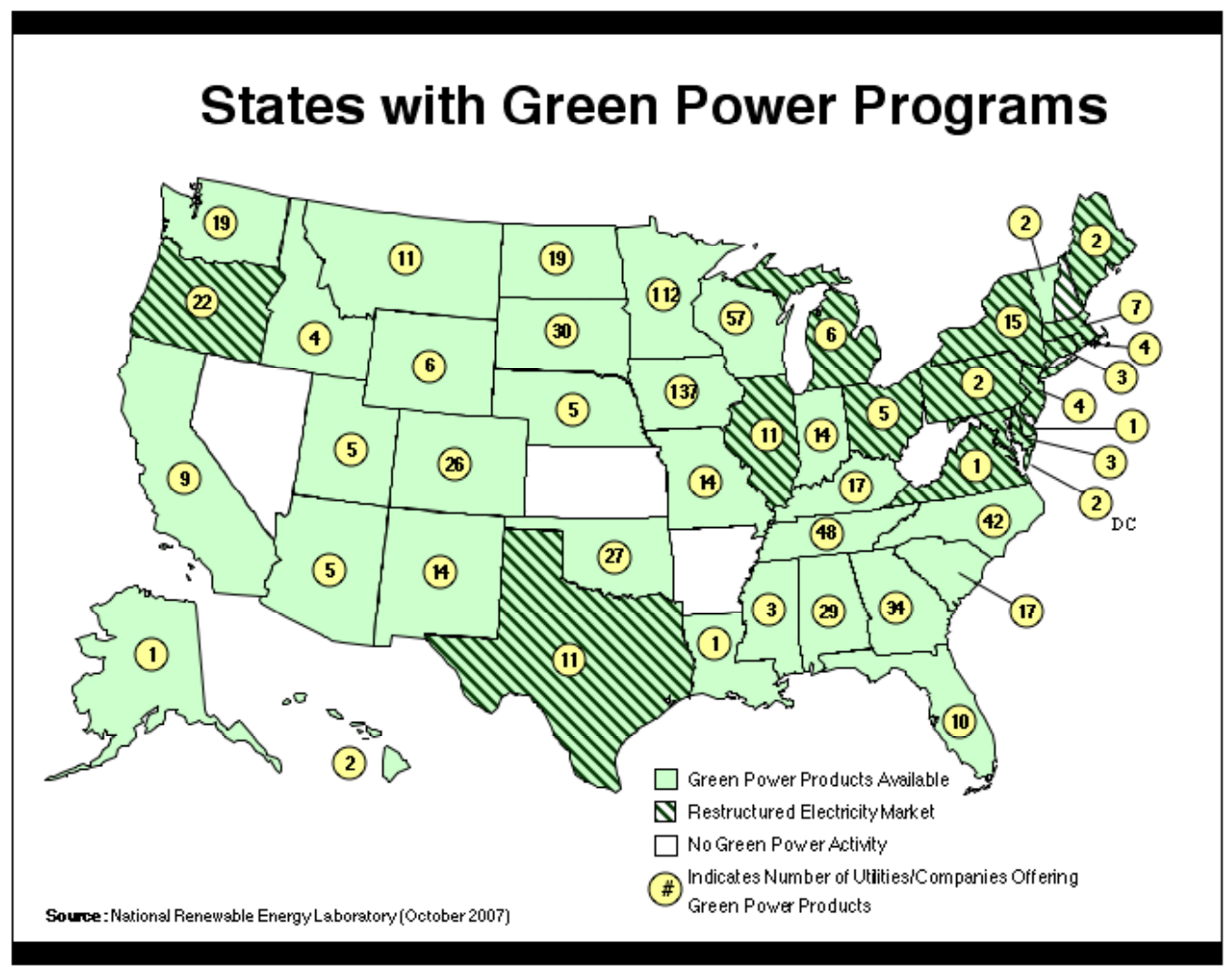

Figure 2. Map of Green Power Providers in U.S. Source: NREL 


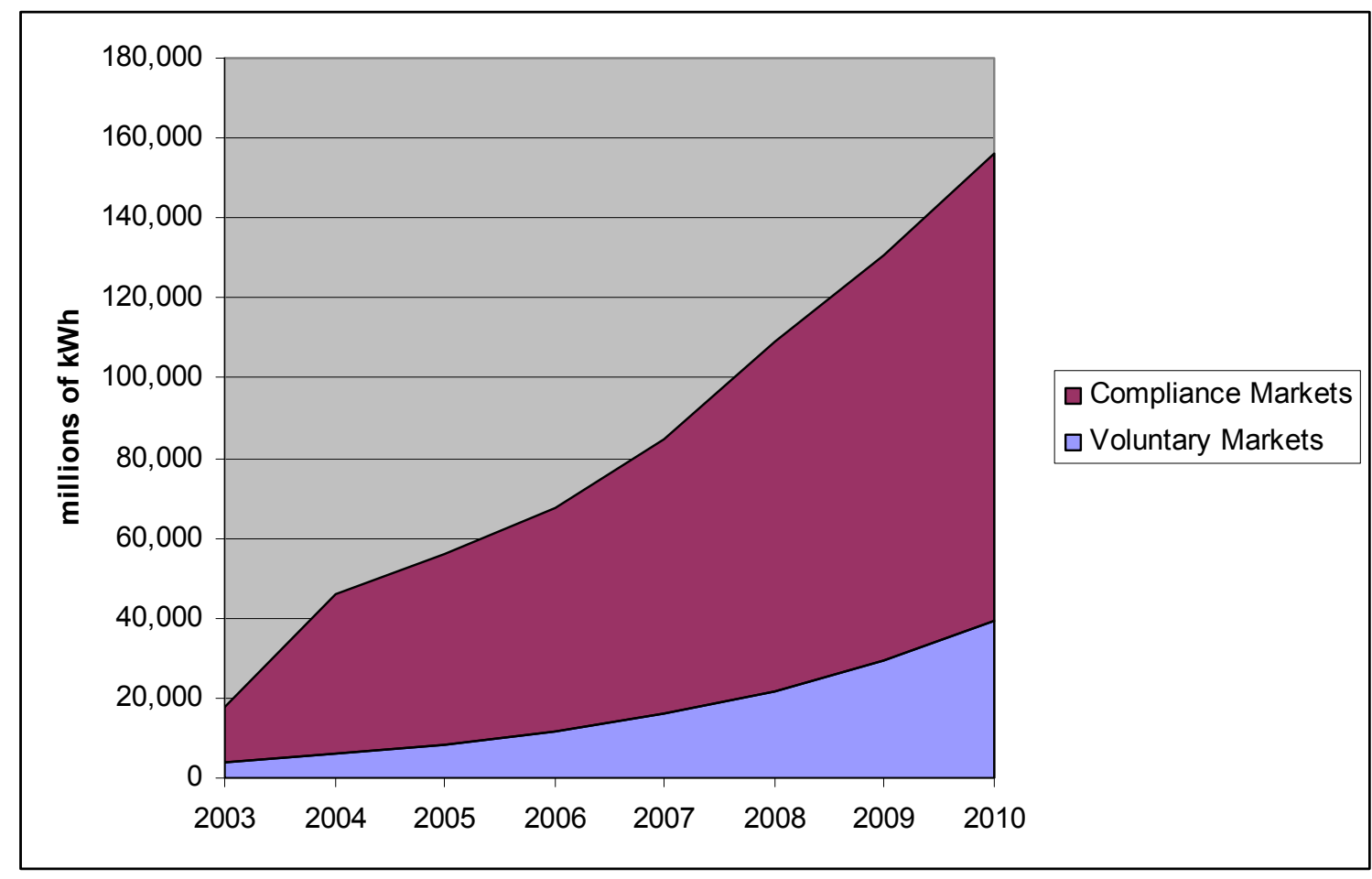

Figure 3. Historical and Projected Voluntary and Compliance Market Growth Source: Estimate of RPS demand for new renewable generation from Union of Concerned Scientists (UCS). Voluntary market demand data from NREL and projected out to 2010 assuming $35 \%$ annual growth rate.

RECs that are sold separate from electricity are an increasingly important piece of the green power market, making up about half of total voluntary market renewable energy sales (on a kWh basis). ${ }^{14}$ The voluntary market has grown rapidly in recent years because businesses, cities, universities, and other large entities have begun making large purchases to meet their corporate or institutional environmental goals and to "green-up" their image. Currently, PepsiCo, Wells Fargo, and Whole Foods are the largest purchasers of RECs. ${ }^{15}$ Interest and participation in the EPA Green Power Partnership, which provides recognition for businesses that have made large renewable energy purchases, has surged in recent years, with annual purchase commitments increasing from 4 million MWh at the end of $2005^{16}$ to 10 million MWh as of August 2007. ${ }^{17}$

\section{Market Interaction Experience and Issues}

The compliance and voluntary markets have already begun to influence each other in a variety of ways. One issue that has emerged is whether the same $\mathrm{kWh}$ of renewable energy can be sold to a consumer making a voluntary purchase while it is also counted toward RPS compliance. This section also explores some of the supply and demand interactions of these two markets and the implications for REC prices, based on experience to date. 


\section{Market Additionality and Double Counting}

For consumers making voluntary purchases of renewable energy, one of the biggest potential problems is that their purchase will not go above and beyond (or be additional to) renewable energy called for by mandates. Otherwise, they are paying a premium for renewable energy that would have been brought online anyway and paid for by all ratepayers. According to the U.S. Environmental Protection Agency (EPA), "It is this 'additionality' that gives voluntary green power purchases their environmental integrity and marketability and, thus, underpins an effective voluntary market." ${ }^{18}$ On the other hand, a few states have allowed double counting to minimize utility compliance costs with RPS policies. Holt and Wiser (2007) summarize arguments that have been presented both for and against counting green power sales toward an RPS. ${ }^{19}$ Double counting can also occur if the same RECs are supplied to different consumers. Concerns over double counting can be addressed through tracking systems, RPS implementation rules, and third-party certification of renewable energy products offered in voluntary markets. Each of these is discussed below in turn.

\section{Role of Tracking Systems in Addressing Double Counting}

Several Web-based tracking systems have emerged to verify RPS compliance and voluntary market transactions. These regional tracking systems help states keep track of RECs that may have been bought and sold several times. A REC used for compliance purposes or purchased in the voluntary market can be "retired" so that it is not resold to other entities. When a megawatt-hour (MWh) of electricity is generated and the associated REC produced, the regional tracking system records the exact date, facility location, vintage, emissions, renewable energy resource, and certificate issue date of the REC and assigns it a unique serial number. Tracking systems follow ownership changes and when the REC is used for marketing claims or RPS compliance, its serial number is retired and not able to be traded again within the system. ${ }^{20}$ This type of system can help ensure that only one entity has benefited from the claim of purchase. However, tracking systems do not prevent a state from counting voluntary retirements towards an RPS target, if the state so chooses.

In New England, the Generation Information System (GIS), run by the New England Power Pool (NEPOOL), issues certificates for all generation in the region. The Generation Attributes Tracking System (GATS) is operated by the Pennsylvania-JerseyMaryland (PJM) regional transmission organization and includes Mid-Atlantic and parts of some Midwestern states. New Jersey participates in the PJM tracking scheme, but also has its own program for tracking solar generation because the state RPS has a solar setaside and allows behind-the-meter solar to be eligible. Texas has its own tracking system which is administered by the Electric Reliability Council of Texas (ERCOT). Two new tracking systems, known as the Western Renewable Energy Generation Information System (WREGIS) and the Midwest Renewable Energy Tracking System (M-RETS), came online during the summer of 2007. In addition, a New York tracking system is expected to come online sometime in 2008 or 2009. Despite the availability of these 
regional tracking systems, not all states are covered, making it difficult to track and verify RECs from those states (see Figure 4).

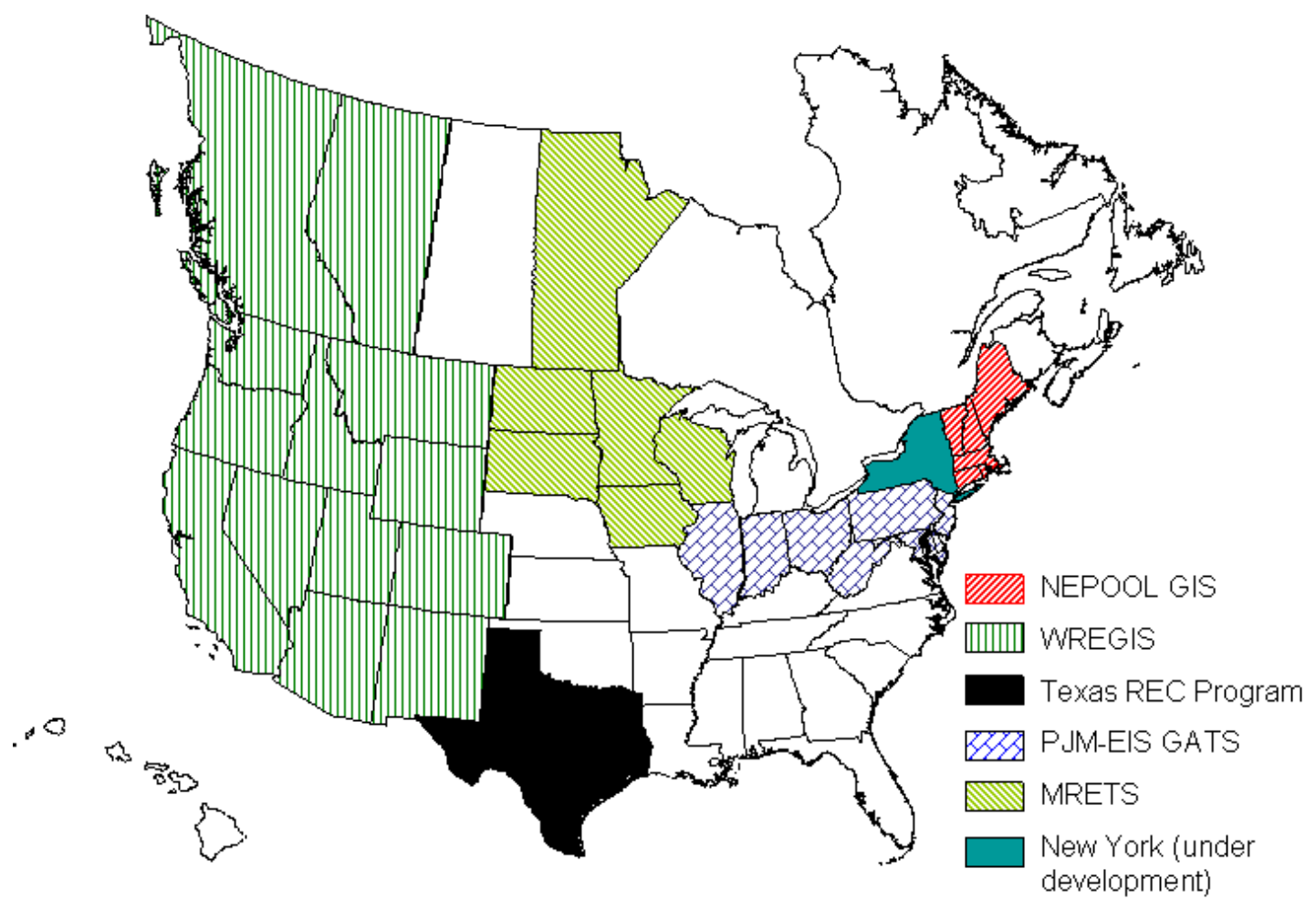

Figure 4. Map of Regional Tracking Systems

\section{Treatment of Voluntary Purchases in RPS Rules}

In addition to tracking systems, rules implementing state RPSs often address the issue of double counting. See Table 3 for a summary of how individual states treat REC purchases. While a few states do allow voluntary market sales to meet RPS requirements to minimize utility compliance costs, most states do not allow voluntary purchases to count toward an RPS, and a few states are silent on the issue.

More than a dozen states and the District of Columbia explicitly prohibit voluntary purchases of renewable energy (or voluntary RECs) from fulfilling state mandates. For example, Minnesota's legislation states: "In meeting their renewable energy objectives, utilities shall not include generation purchased under green pricing programs." ${ }^{21}$

A few states allow exceptions to this no double-counting rule. In Delaware, Maine, and Rhode Island, the RPS legislation allows a percentage (up to the state mandate level) of individual, voluntary, green power purchases to count toward fulfillment of the RPS. So, if a customer purchases $100 \%$ renewable energy, in Maine where the RPS requirement is $30 \%, 30 \%$ of the voluntary purchase can count toward the RPS. In Maryland, renewable energy that is sold in the voluntary market is deducted from the baseline electricity sales 
used to determine the amount of sales necessary to fulfill the state RPS. ${ }^{22}$ In Colorado, RECs sold in the voluntary market can be counted toward the RPS if the Public Utilities Commission provides approval.

In Texas, the RPS was expanded and amended in 2005 to include a provision which required all renewable energy capacity and generation to count toward the RPS. ${ }^{23}$ This provision essentially meant that any RECs from Texas renewable generators that were sold into voluntary markets would be double counted, because they would also be counted toward the RPS by default. As it does not allow this type of double counting, the Green-e certification program refused to certify RECs from Texas while this provision was in the RPS statute. Generators in the state were producing more RECs than were needed for compliance with the RPS, and without the ability to sell into the voluntary market, they were left with a large surplus. According to one estimate, there was more than 1000 MW of excess renewable energy capacity in Texas in 2006 after RPS obligations were met. ${ }^{24}$ And, voluntary market suppliers, which have relied on Texas RECs for a significant amount of the voluntary REC supply, did not have this market to draw upon. The Texas legislature recently removed this requirement, and Green-e is once again certifying voluntary market RECs from Texas. ${ }^{25}$

Connecticut, Hawaii, and Iowa have not yet addressed whether voluntary RECs can fulfill the RPS. Illinois requires RECs to be retired once they are used for RPS compliance, which may avoid double counting; however, further clarification may be needed. Further, tracking systems in the Northeast and Midwest retire certificates preventing them from being used in the future, thus, double counting may be restricted in most of these states. But the lack of clarity in state rules may allow a REC to be used for compliance and again to support a claim within the voluntary green power market. ${ }^{26}$

Arizona, Wisconsin, and Vermont are the only states that explicitly allow double counting of RECs. Wisconsin's rules allow the extra cost of fulfilling the RPS to be recovered through charging voluntary customers a premium for green energy, but according to data reported to NREL, no utilities have elected to count green power sales toward RPS compliance. ${ }^{27}$ Arizona allows voluntary purchases to fulfill the state RPS and applies a credit multiplier of up to 2 in order to promote voluntary market purchases. ${ }^{28,29}$ Vermont's Renewable Portfolio Goal calls for load-serving entities to procure electricity from renewable energy generators to meet the targets. The RECs associated with this generation can be sold separately to voluntary customers or other states for compliance purposes. ${ }^{30}$ Generally, these states have allowed voluntary market renewable energy sales to count toward the RPS to minimize utility compliance costs. Critics of Arizona and Vermont's policies toward double counting of voluntary RECs claim that if the RPS is beneficial to all state residents, then its cost should be shared equally. Whereas, if double counting is allowed, voluntary purchasers of RECs incur the cost of mandatory compliance in addition to paying a premium for green power. ${ }^{31}$ 
Table 3. State Treatment of Voluntary Purchases in RPS Compliance

\begin{tabular}{|c|c|c|}
\hline State & $\begin{array}{r}\text { Double } \\
\text { Counting } \\
\text { Allowed }\end{array}$ & Explanation \\
\hline $\mathrm{CA}$ & No & $\begin{array}{l}\text { REC can only be used once for compliance with RPS or verifying } \\
\text { retail product claims }\end{array}$ \\
\hline $\mathrm{DC}$ & No & $\begin{array}{l}\text { No RECs derived from voluntary purchases of energy can count } \\
\text { toward its RPS }\end{array}$ \\
\hline MA & No & Suppliers must show that RECs are not used twice \\
\hline MN & No & $\begin{array}{l}\text { Utilities shall not include generation purchased under green pricing } \\
\text { programs in meeting their RPS }\end{array}$ \\
\hline MT & No & $\begin{array}{l}\text { A public utility may not resell RECs and count those sold to meet } \\
\text { RPS obligation }\end{array}$ \\
\hline $\mathrm{NC}$ & No & $\begin{array}{l}\text { Energy credited toward RPS compliance shall not be credited } \\
\text { toward any other purpose, including voluntary purchase programs }\end{array}$ \\
\hline $\mathrm{NH}$ & No & $\begin{array}{l}\text { REC may not be used for RPS compliance if otherwise sold, retired, } \\
\text { or claimed }\end{array}$ \\
\hline $\mathrm{NJ}$ & No & The same RE cannot be used to satisfy two REC claims \\
\hline NM & No & $\begin{array}{l}\text { Premium-priced renewable energy sold to consumers cannot count } \\
\text { toward the RPS }\end{array}$ \\
\hline NV & No & $\begin{array}{l}\text { Generator must attest that green energy cannot be sold or used for } \\
\text { credit in another state }\end{array}$ \\
\hline NY & No & $\begin{array}{l}\text { Voluntary purchases cannot count toward } 24 \% \text { mandatory RPS } \\
\text { requirement }\end{array}$ \\
\hline OR & No & $\begin{array}{l}\text { Sales from voluntary green power programs cannot count toward } \\
\text { RPS }\end{array}$ \\
\hline PA & No & $\begin{array}{l}\text { RPS can not be satisfied with alternative energy credits already } \\
\text { purchased by individuals businesses }\end{array}$ \\
\hline TX & No & Law passed in June of 2007 prevents double counting \\
\hline WA & No & $\begin{array}{l}\text { Eligible renewable resource, distributed generation, and green } \\
\text { pricing cannot be used twice }\end{array}$ \\
\hline $\mathrm{CO}$ & Sometimes & Utilities must apply to the PUC to double-count; none have \\
\hline DE & Sometimes & $\begin{array}{l}\text { Individual voluntary sales of a percent up to the RPS can count } \\
\text { toward compliance }\end{array}$ \\
\hline MD & Sometimes & Voluntary sales not included in percent base to which RPS applies \\
\hline $\mathrm{ME}$ & Sometimes & $\begin{array}{l}\text { Individual voluntary sales of a percent up to the RPS can count } \\
\text { toward compliance }\end{array}$ \\
\hline $\mathrm{RI}$ & Sometimes & $\begin{array}{l}\text { Individual voluntary sales of a percent up to the RPS can count } \\
\text { toward compliance }\end{array}$ \\
\hline$A Z$ & Yes & Utilities able to count green pricing sales toward RPS \\
\hline WI & Yes & $\begin{array}{l}\text { Law allows double counting, but most utilities report that they do not } \\
\text { count green pricing sales toward RPS }\end{array}$ \\
\hline
\end{tabular}

*Note: CT, HI, IA and IL have not yet explicitly addressed the use of voluntary green power purchases to fulfill the state RPS. Sources: Information in table is derived from DSIRE database http://www.dsireusa.org and Ed Holt and Ryan Wiser, "The Treatment of Renewable Energy Certificates, Emissions Allowances, and Green Power Programs in State Renewable Portfolio Standards," Lawrence Berkeley National Laboratory, LBNL-62574, April 2007, pg 23-26.

**Utilities have reported to NREL that they do not count green pricing sales toward RPS requirements. 


\section{Third-Party Certification of Products in Voluntary Markets}

As ambiguous language in some RPS implementation rules could allow for double counting, steps have been taken to create certification bodies or rules to avoid it. For example, the U.S. Environmental Protection Agency's (EPA) Green Power Partnership has established standards for renewable energy and REC purchases by its more than 750 partners, which include Fortune 500 companies, universities, and other business and institutional customers. Most large nonresidential customers that purchase green power participate in the partnership and follow the program rules. To qualify for the program, voluntary purchases must not be counted toward an RPS and the renewable energy or RECs must come from new renewable energy sources built on or after January 1, 1997. This stipulation ensures the renewable energy purchase is not double counted and helps promote new renewable energy development. ${ }^{32}$

The Green-e program, which is managed by the Center of Resource Solutions, has a similar requirement. Green-e will recognize only RECs that are not used to meet a regulatory requirement and are sourced from "new" installations that were built after January $1,1997 .{ }^{33}$ Green-e is the largest certification program, certifying about $50 \%$ of all voluntary renewable energy purchases. ${ }^{34}$

On the other hand, the Ecopower program, managed by Environmental Resources Trust (ERT), may be used to certify electricity that has been used to fulfill an RPS, if the state RPS legislation allows the same REC to be sold in both the compliance and voluntary markets. ${ }^{35,36}$ ERT's Ecopower label provides a record of the claim of renewable energy put into the grid, and certified generation must be $100 \%$ renewable and derived from generators built after January 1, 1998. c, $37^{2}$

Despite the potential for double counting in some regions, generally very little double counting occurs, because of the combination of certification programs, state rules prohibiting double counting, tracking systems, and the EPA Green Power Partnership program requirements. Nonetheless, some green power marketers sell RECs that are not certified, and some purchasers do not participate in the EPA partnership program. Residential consumers, in particular, may not be aware of this issue and the need to seek certification. To alleviate concerns about double counting and protect consumers, state rules can be designed to clearly prohibit double counting, and REC tracking systems can be used to verify and ensure that double counting does not occur.

\section{Demand Interactions of the Two Markets}

While the existence of two markets for renewable energy can prove problematic when attempting to prevent the double use of RECs, having two separate markets helps promote renewable energy development. Project developers and financers have more confidence in the ability to find buyers for RECs because they can be sold into two separate markets that have separate purchasing requirement time frames. Also, the

\footnotetext{
${ }^{\mathrm{c}}$ Prior to January 1, 2007, Ecopower ${ }^{\mathrm{SM}}$ product had to contain $10 \%$ renewable energy, and $50 \%$ had to come from new or existing renewable sources.
} 
markets may be complementary in that they provide support for different renewable energy technologies or renewable energy generated in different regions.

\section{Complementary Timing and Demand}

The existence of both the voluntary and compliance green power markets can provide two different revenue streams for renewable energy developers, reducing project risk and bolstering finances. ${ }^{38}$ The availability of the two markets for project output can also help alleviate some supply and demand balance issues. As an example, the compliance market has, in recent years, been the major driver for new renewable energy development in the nation, particularly wind energy. ${ }^{39}$ However, because RPS targets increase over time and renewable energy projects generally cannot be incrementally scaled up, there can be an excess of supply in compliance markets as large projects come online with excess capacity to meet near-term goals. When both markets exist, this near-term excess supply can be used to address demand in the voluntary market.

For example, some utilities have found that it is beneficial to have a green pricing program when an RPS is in place because it provides increased flexibility for managing renewable energy supplies. By being able to periodically reallocate eligible renewable energy generation from the voluntary program to the compliance obligation and vice versa, utilities can better balance supply and demand, which helps minimize costs and facilitate resource planning. ${ }^{40}$

Additionally, the presence of two markets can provide assurances to developers and project financers that markets will be sustained. In Pennsylvania, for example, the voluntary market helped support the development of five wind farms prior to the adoption of the state's Alternative Energy Portfolio Standard (AEPS), but emerging RPS policies in the region also provided some assurances that markets for the project output would persist over time. For example, Community Energy sold the output of three of these wind farms - Sommerset, Mill Run, and Waymart - to end-use customers such as Pennsylvania State and Carnegie Mellon Universities. Two other wind farms in Garrett and Meyersdale, Pennsylvania also sold RECs in the voluntary market before the AEPS was adopted. The ability of renewable generation located within Pennsylvania to fulfill other state RPS requirements in the region helped assure project developers that there would be a sustained market for the RECs, but it was the voluntary market that provided the initial drive for investment in this state. ${ }^{41}$

Furthermore, some states limit the length of time that RECs are eligible to be used for compliance. Limits on the lifetime of RECs can range from three months to four years after they have been issued. ${ }^{42}$ Therefore, the presence of voluntary markets can provide another market for RECs with a short compliance lifespan, providing a more consistent selling market. 


\section{Support for Technology and Geographic Diversity}

Just as both markets can provide revenue streams for project developers, the voluntary and compliance markets can support different types of renewable generation in various locations. For example, often voluntary markets support renewable energy generation from regions where it is not eligible for RPS compliance. In some cases, however, there may be overlap in state RPS and voluntary market demand if green power customers are interested in purchasing local renewable energy generation in regions where an RPS is in place.

In the compliance market, the least expensive form of renewable electricity within the eligible geographic region will generally be used to fulfill the mandate. ${ }^{43}$ However, some states have incorporated provisions in their RPS that encourage in-state, customer-sited, or community-based renewable energy generation, or require that a certain fraction of the target be met with specific resources, such as solar or biomass. For example, a number of states require a percentage of the RPS to be fulfilled with solar energy. In addition, New York requires that a percentage of the RPS be filled from customer-sited generation such as fuel cells, methane digesters, small wind, or photovoltaic cells. ${ }^{44}$

Similar to technology set asides in RPS policies, voluntary markets have also been used to provide support for specific technologies or small-scale renewables. Consumers generally show a preference for solar and wind energy sources; therefore, many products are designed to cater to these preferences. ${ }^{45}$ For example, a number of utilities, such as the Tennessee Valley Authority (TVA), include some generation from small-scale solar photovoltaic and wind projects in the resource mix used to supply their green power customers. TVA's green power program provides a significant incentive for the development of small, distributed PV and wind systems in the region, in the form of a $15 \notin / \mathrm{kWh}$ payment to system owners for the output for 10 years. ${ }^{46}$ We Energies' green pricing program is similar in that it supports the development of customer-sited PV systems by paying system owners $22 \notin / \mathrm{kWh}$ for the output of the system.

In contrast to some RPS policies that limit eligible renewable generation to a specific region, the voluntary market is increasingly providing an outlet for RECs from facilities located anywhere in the U.S. For instance, many large corporations and institutional customers purchase "nationally sourced" RECs, which are often derived from renewable energy projects that are not eligible to meet an RPS because of their location. In addition, voluntary markets have helped stimulate renewable energy development in regions prior to the adoption of an RPS. For example, utility green pricing programs in the Pacific Northwest have created demand for wind energy in the region, supporting projects such as the Stateline wind energy project on the Washington-Oregon border. ${ }^{47}$

In some cases, voluntary markets are also used to support "local" renewable energy sources located near the purchaser. Some consumers prefer and are willing to pay more for state or regionally derived renewable energy because they want to support local development of the industry. For example, under the Connecticut Clean Energy Options program, a portion of the power is sourced from the ISO New England, providing support 
for regionally-sourced renewables. ${ }^{48,49}$ In addition, many utility green pricing programs are sourced from renewable energy facilities located within the state or neighboring states. In these instances, the demand from the voluntary and RPS markets may overlap, creating competition for the same local resources. This overlap and the price implications are discussed more below.

\section{REC Price Interactions}

This section explores the elements that drive the price of RECs and discusses the price effects resulting from the presence of the two markets. First, we discuss compliance market prices as these markets tend to establish prices in regions where RPS policies exist. Then we turn to voluntary market REC prices and the price interactions between the markets.

\section{Compliance Market Prices}

The way in which RPS rules are written can determine the price of compliance RECs. Variation in RPS rules among states can, in turn, result in large variations in REC prices from state to state. Whether or not a state has good renewable energy resource potential, the ease or difficulty in siting new projects, and the rules pertaining to eligible resources are also significant determining factors in the price of a REC. If preexisting renewable generation qualifies for an RPS or if the eligible technology definition or eligible compliance region is very broad, states will be less likely to have REC supply shortages. Prices can spike to near the compliance penalty when such shortages arise.

For example, Massachusetts has experienced a shortage of RECs which has driven prices up to near the Alternative Compliance Payment of $\$ 57 / \mathrm{MWh} .{ }^{50,51}$ This price is an order of magnitude higher than REC prices in Texas for instance, where REC supplies have been plentiful. To date, Maine compliance RECs have traded at very low prices because the RPS has allowed preexisting renewable resources like hydropower and biomass to qualify, although prices are expected to rise with the updated law requiring new resources. Connecticut's Class I REC prices were high at approximately \$35 until April of 2005 when the RPS was changed to accept existing biomass generators, causing prices to bottom out at approximately $\$ 5$ in August of 2005. ${ }^{52}$ In 2006, the Connecticut legislature changed the RPS again to clarify that construction and demolition sources of biomass do not qualify as sustainable, and the price is now back up to approximately $\$ 50 .^{53}$ Thus, changes in eligible resources can have a dramatic affect on prices.

Rules with respect to banking or limitations on the life of REC eligibility can also affect prices. If a state has set up rules in its RPS that allow RECs to be banked and used in future years, as is the case in Texas, REC supply and price oscillations could occur if load serving entities attempt to hoard RECs when prices are low. ${ }^{54}$ However, banking can also alleviate price spikes by providing flexibility in compliance. The variety of rules regarding resource eligibility, REC origin, and bankability of RECs has led to a large discrepancy in REC prices from state to state. See Figure 5 for a summary of compliance 
REC prices for Tier 1 or Class 1 sources (typically new renewable energy sources) by state since August of 2002.

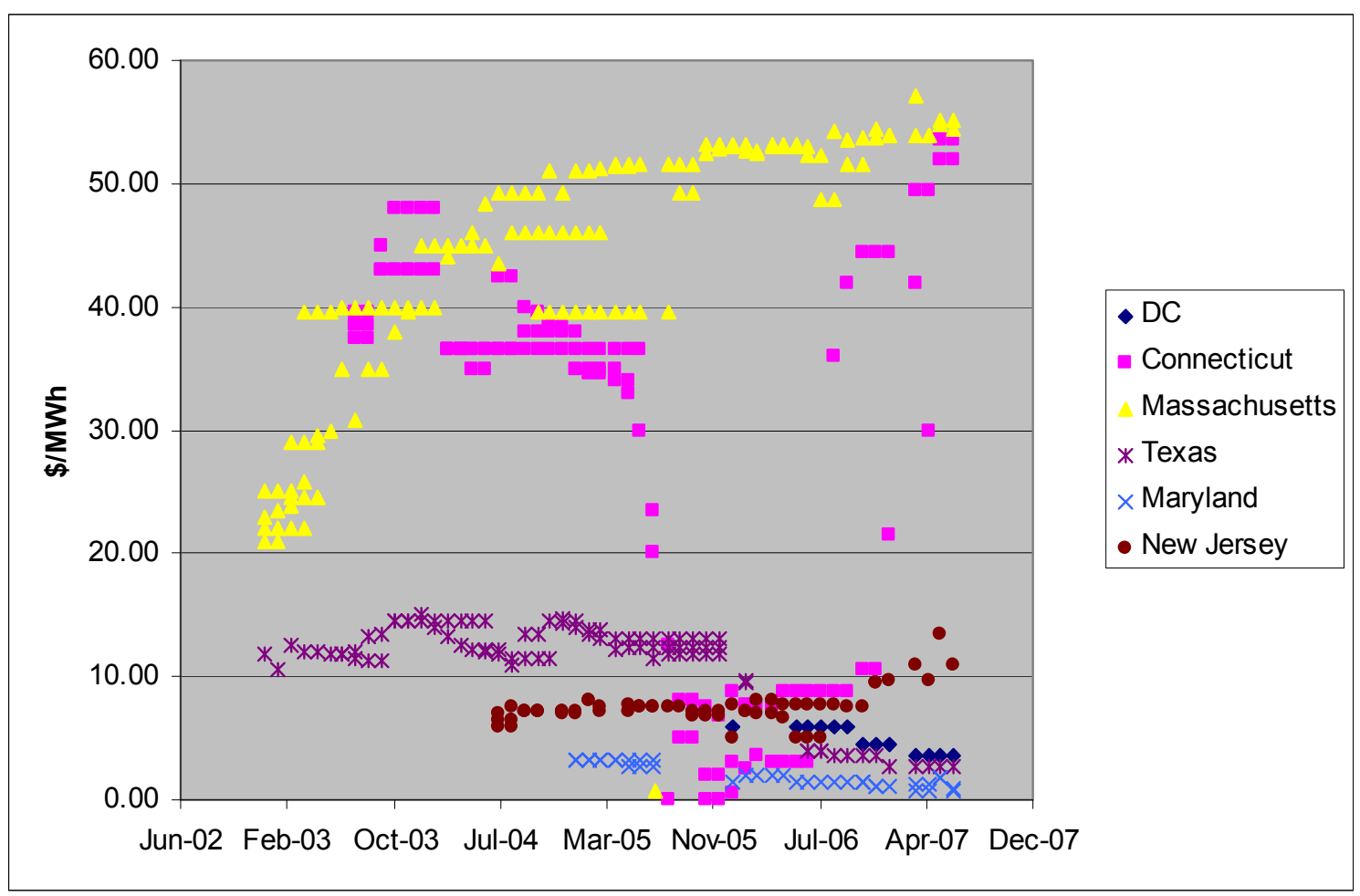

Figure 5. Compliance REC Market Prices

Source: Graph developed by Lawrence Berkeley National Laboratory based on data from Evolution Markets.

\section{Voluntary Market Prices}

As just discussed, compliance market requirements and the availability of supplies to meet them tend to drive REC prices in each region. However, in many cases, voluntary market providers are not bound to geographic regions for REC supplies, in which case they can procure nationally sourced RECs, which are generally less affected by regional compliance market prices. It is also important to note that in the voluntary market, the availability and price of supplies can affect demand, with demand rising with low prices, and falling with high prices.

Overall, voluntary REC prices depend on several factors: the type of renewable energy generation, the geographic origin of generation, the vintage of the renewable energy project, the size of the purchase, and availability of supplies. Prices for residential retail consumers range from about $1 \notin / \mathrm{kWh}$ to $2 \phi / \mathrm{kWh}$. For large consumers, prices are considerably lower. Limited data available from brokers provides an indication of wholesale prices. Nationally-sourced RECs from wind farms in the Midwest, where the wind resource quality is generally excellent, range from $\$ 1 / \mathrm{MWh}$ to $\$ 4 / \mathrm{MWh}$ and prices for biomass range from about $\$ 1 / \mathrm{MWh}$ to $\$ 5 / \mathrm{MWh}$. Solar-derived RECs tend to be the 
most expensive at about \$20/MWh. ${ }^{55}$ See Table 4 for a summary comparison of voluntary REC prices by region and technology for 2006.

Table 4. 2006 Wholesale/Large Commercial Voluntary REC Prices (New Renewables)

\begin{tabular}{|l|l|l|l|}
\hline Generation Type & $\begin{array}{l}\text { Midwest } \\
\$ / \mathrm{MWh}\end{array}$ & $\begin{array}{l}\text { West } \\
\text { \$/MWh }\end{array}$ & $\begin{array}{l}\text { National } \\
\$ / \mathrm{MWh}\end{array}$ \\
\hline Biomass & & $\$ 3-10$ & $\$ 1-5$ \\
\hline Solar & & $\$ 18-21$ & $\$ 21$ \\
\hline Wind & $\$ 1-4$ & $\$ 3-7$ & $\$ 1-4$ \\
\hline Geothermal & & $\$ 1-7$ & \\
\hline
\end{tabular}

Source: Evolution Markets

${ }^{*}$ Offer and bid prices averaged to estimate sale price

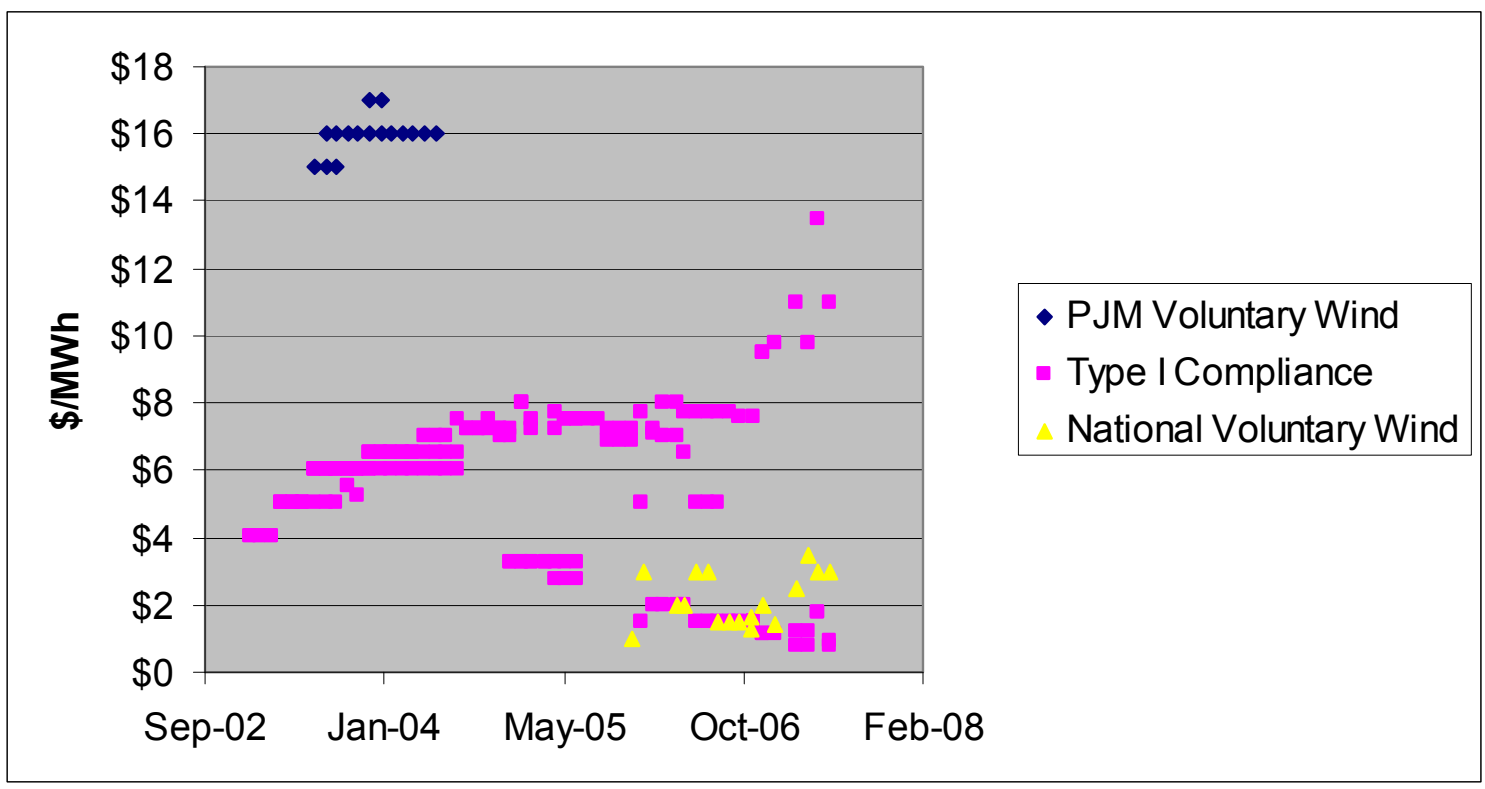

Figure 6. Voluntary and Compliance REC Prices for the PJM Region, \$/MWh Source: Evolution Markets

If voluntary market demand overlaps with the RPS region, compliance markets will have greater influence on voluntary market prices. The price of RECs in the voluntary market can be affected by REC availability after compliance obligations have been met. Generally, compliance obligations are met first, as many RPSs include noncompliance penalties. In the PJM region, voluntary REC prices were about $\$ 10 / \mathrm{MWh}$ more expensive than compliance REC prices from December 2004 to January 2005 because RECs derived from this region were scarce at the time (see Figure 6). In addition, one green power marketer in New York recently raised the price of its green power offering and reduced the amount of wind generation in its product mix because of a scarcity of wind energy supplies in the region, as most of the available supplies were used to meet the RPS. ${ }^{56}$ The opposite can be true if utilities achieve RPS compliance ahead of schedule and there is an oversupply of available renewable energy in the region. 
In the coming years, both voluntary and compliance REC prices could rise as existing RPS requirements increase, as RPS policies are expanded to other states and perhaps nationally, and if REC supplies in some states and for certain technologies become increasingly scarce. ${ }^{57}$ If there is a marked increase in the demand for RECs without an accompanying growth in supply, the voluntary market would likely be the first to experience a shortage as utilities buy up the available RECs to avoid noncompliance penalties. A preliminary analysis conducted by NREL shows a potential short-term REC supply shortage nationally through 2010, given established state RPS targets and projections of voluntary market demand based on recent growth rates. ${ }^{58}$ While the analysis did not address regional supply and demand issues, shortages would likely occur in particular regions, because excess generation in some areas, like Texas, is not eligible to meet RPS requirements in other states. It is important to note, however, that shortages would likely be short-term in nature, as the industry would likely ramp up to meet growing demand.

\section{Relationship between RPS and Voluntary Market Participation}

This section explores whether voluntary market participation influences RPS adoption and expansion and vice versa. For example, voluntary markets may play a role in influencing the adoption of an RPS by demonstrating consumer support for renewable energy. On the other hand, once an RPS is established, will it cause participation in voluntary markets to decline? Is there a need for voluntary markets if compliance obligations are established? This section examines these issues in turn.

\section{Voluntary Market Influence on RPS Adoption}

In some instances, voluntary market demand has demonstrated consumer support for renewable energy, contributing to the development or expansion of RPS policies. Consumer support for renewable energy can be an important consideration for policymakers considering an RPS and voluntary market participation can be an indicator of that interest and support. For example, in Colorado the voluntary market was an important driver for wind energy development in the mid to late 1990s prior to the adoption of an RPS. In 1996, Colorado's major investor-owned utility, Xcel Energy, began offering a voluntary green pricing program called Windsource to its customers to prepare for what it saw as a possible transition to a deregulated, competitive marketplace. The program's popularity caused Xcel to procure additional wind energy to meet the Windsource demand. The success in the voluntary market demonstrated that there was popular support for renewable energy and set the stage for the adoption of a statewide RPS by a voter-approved ballot initiative in $2004 .{ }^{59}$ Similarly, success of utility green pricing programs in Wisconsin helped facilitate the expansion the state's RPS in $2006 .{ }^{60}$ Because of the emphasis on marketing, voluntary green power programs can raise awareness and educate consumers about the benefits of renewable energy in general, which may be important to the passage of an RPS. 


\section{RPS Influence on Voluntary Market Participation}

As more aggressive RPS standards are adopted by states and bills for national legislation gain momentum, there is some concern that the voluntary market will dissolve as customers begin to rely on policies to support renewable energy. However, there is little evidence to date to suggest that the adoption of an RPS will impact voluntary market sales. Figure 7 shows the historic and current sales of renewable energy through green pricing programs in four states with an RPS in place. ${ }^{61}$ The year that the RPS was adopted or modified is listed in parentheses in the legend of the figure. There is no apparent decline in sales once the RPS is adopted, at least to date. In fact, sales continue to grow over time.

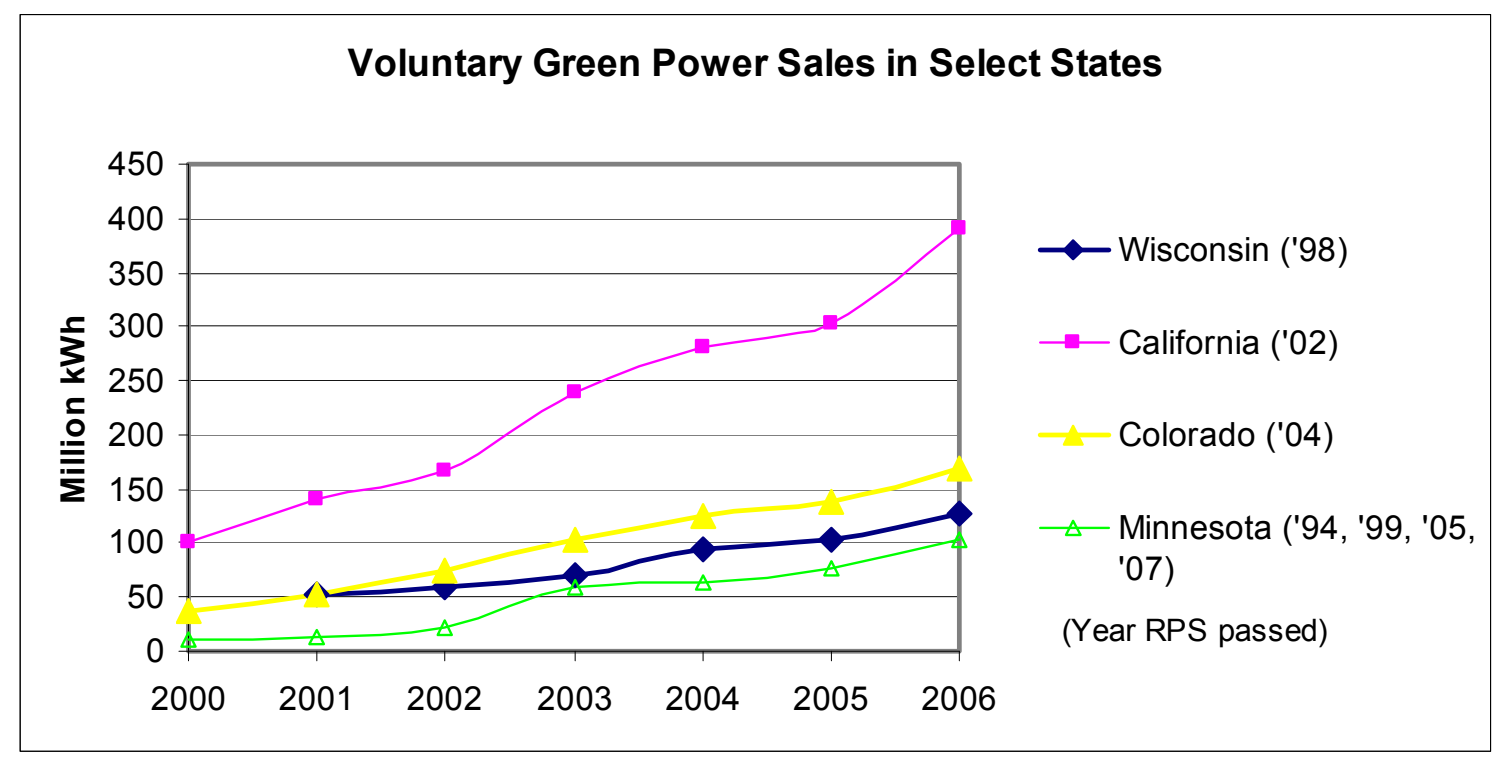

Figure 7. Voluntary Green Power Sales in Selected States with RPS

Furthermore, we found that customer participation rates in utility green power programs were higher on average in states with an RPS than in those without. This finding was statistically significant based on an analysis of 2006 customer participation data provided by utilities ${ }^{\mathrm{d}}$. While it is not likely that the mere presence of an RPS encourages consumers to make voluntary green power purchases, the higher voluntary participation rates in states with RPS may be explained by a number of factors, such as: 1) consumers in RPS states may be more prone to support renewable energy in general, 2) consumers may be more aware of the benefits of renewable energy due to education about the benefits of the RPS policy, 3) some successful green pricing programs may be offered by public or cooperative utilities that are not subject to the state RPS, and 4) there may be more renewable energy supplies in states with an RPS which keeps prices relatively low

\footnotetext{
${ }^{d}$ This finding was based on a t-test for equality of means. Mean customer participation rates for utility programs were 0.59 percent and 2.1 percent for programs in states without RPS $(\mathrm{N}=16)$ and states with RPS $(\mathrm{N}=65)$, respectively. The difference in means was significant at the 0.01 level.
} 
for green power consumers, encouraging participation. Interestingly, we found no statistically significant difference in average renewable energy sales rates $(\mathrm{kWh}$ of green power sold divided by all $\mathrm{kWh}$ of electricity sold by the utility) through utility green power programs in states with and without an RPS.

Figure 8 shows the relative magnitude of renewable energy sales through utility green power programs by state and whether an RPS policy has been enacted. The figure shows that many of the states that lead in terms of consumer purchases through voluntary utility green power programs also have RPS policies in place. The notable exceptions are Florida, Tennessee, and Oklahoma.

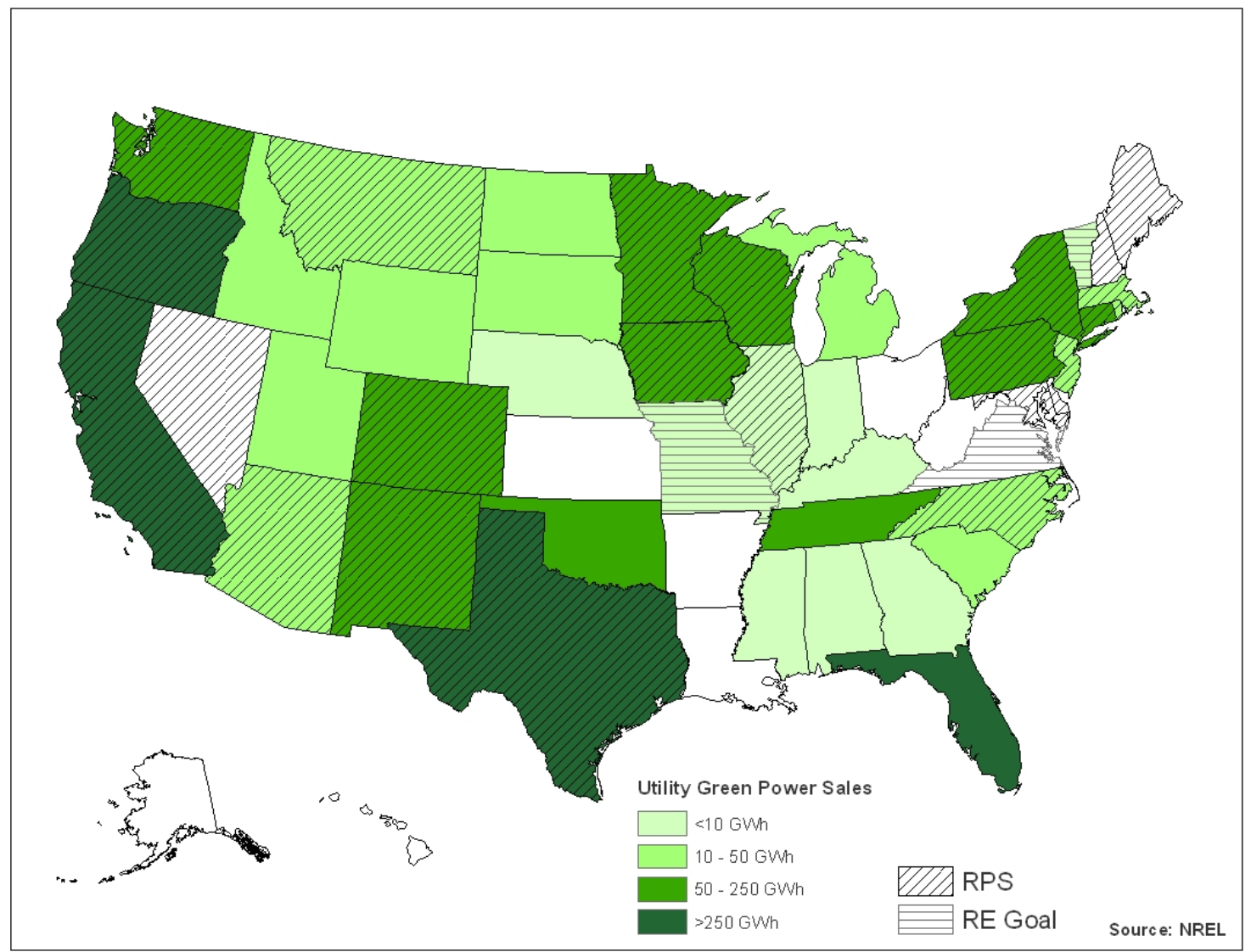

Figure 8. Voluntary Green Power Purchases through Utility Programs in States with RPS

Even though these data suggest that voluntary market sales remain robust in states with an RPS, looking forward, this issue might require additional analysis once higher RPS penetration levels are achieved. It is possible that more aggressive policies could impact voluntary market participation. In addition, RPS policies could limit sales or participation if supply shortages were to arise, as discussed earlier. In this case, compliance obligations would likely be met first and utilities might limit renewable energy available to voluntary green pricing programs, for example. Or higher prices might discourage participation. However, it is likely that such shortages would be short term in nature. 


\section{Summary and Conclusions}

Both voluntary and compliance renewable energy markets have gained momentum in recent years. A number of drivers - including concern over global climate change, local air pollution, a desire for energy independence, and expectations of increased job creation-have led to a proliferation of state renewable energy mandates. The number of voluntary customers choosing to pay a premium for renewable energy has also increased as they view their purchases as a way to mitigate these concerns for a reasonable price.

As the voluntary and compliance markets have evolved and grown, they have increasingly influenced each other in a variety of ways. Based on our review of experience in these two markets in recent years, there are several key issues that have emerged as a result of the interplay of these two markets, which are described briefly below.

- Double Counting. Double counting is an important concern in the operation of these two markets. This is a particular issue for voluntary markets because the integrity of voluntary markets relies on the ability of consumers to support renewable energy generation, which is additional to generation that is used to meet mandates. If voluntary purchases by consumers do not prompt renewable energy development beyond what would have already been driven by mandates, then voluntary purchasers will shoulder costs that would otherwise have been paid by all ratepayers. Most state RPS rules specify that no double counting is allowed; however, others allow some double counting or are silent on the issue, leaving the potential for it to occur. REC tracking systems are now operational in most regions of the country and can help address concerns over double counting, but there are some regions of the country that do not yet have these systems in place. Clear policies that prevent double counting can help ensure the integrity and viability of voluntary markets going forward. In addition, educating customers about third-party certification would help alleviate concerns over double counting.

- Complementary Markets. While the voluntary and compliance renewable energy markets generally operate separately, they can be complementary in providing multiple revenue streams that operate on different time tables for project developers. RPS targets generally increase incrementally over time and renewable energy projects are often constructed in large increments to take advantage of economies of scale; therefore, available renewable generation may exceed current RPS requirements. Voluntary markets can help provide an alternative market for the output of excess renewable energy capacity, which can be beneficial for project developers. And utilities that are subject to an RPS may find it easier to manage current and future supplies if they also offer a green pricing program.

- Demand for Renewable Energy Generation. While compliance and voluntary markets may sometimes be in competition for renewable energy generation, often the markets utilize renewable energy generation from different regions or technologies. RPS policies typically create demand for the least-cost renewable 
energy generation from within a specified region, unless there are resourcespecific set asides. Voluntary markets utilize a significant amount of renewable energy generation from projects located throughout the U.S., including those in locations that make them ineligible to meet RPS requirements. In addition, some voluntary market products incorporate generation from higher-cost renewables that might not be used to meet RPS requirements, such as small distributed systems.

- Price Interactions. Typically, the RPS market will establish REC prices as a result of enforcement penalties and strict eligibility requirements. If RPS eligibility rules are difficult to meet, REC prices can be driven up by supply shortages. These RPS rules can affect prices for both voluntary and compliance RECs in the region. However, voluntary market RECs are often nationally sourced from projects in areas with high quality renewable resources but where no RPS exists, or where states are in RPS overcompliance. REC prices in the RPS market have had little effect on nationally-sourced REC prices to date.

- Voluntary Market Influence on Adoption of RPS. In some cases, the presence of the voluntary market has demonstrated consumer support for renewable energy development and contributed to the passage of RPS legislation or ballot initiatives. Because of the emphasis on marketing, voluntary green power programs can raise awareness and educate consumers about the benefits of renewable energy in general, which may be important to the passage of an RPS.

- RPS Impact on Voluntary Market Participation. Based on an examination of available data, we found no evidence to suggest that the adoption of RPS policies has adversely affected voluntary purchases of renewable energy to date. Examination of data on utility green pricing program sales in four states showed continued increases in sales, despite the adoption of RPS policies. Furthermore, we found that utility green pricing program participation rates are higher on average in states with RPS, based on a statistical analysis of available utility data. Consumers may remain interested in purchasing renewable energy at levels beyond the minimum requirements of an RPS. However, most RPS policies are in early stages of implementation and this issue may require additional analysis once higher RPS penetration levels are achieved. 


\section{References}

${ }^{1}$ EIA Annual Energy Outlook 2007, Tables 8 and 16, DOE/EIA-0383, Energy Information Agency, February 2007. Total non-hydro renewable energy generation represented $2.8 \%$ of total electricity generation in 2006, according to data from EIA. The estimate of compliance and voluntary markets is derived from Union of Concerned Scientists data on RPS requirements and NREL data on voluntary markets, compared to EIA estimates of total generation.

${ }^{2}$ Wiser, R., Namovicz, C., Gielecki, M., and Smith, R. "The Experience with Renewable Portfolio Standards in the United States." The Electricity Journal; Vol. 20, Issue 4, May 2007; p. 9.

${ }^{3}$ Deyette, J., Union of Concerned Scientists, Email, August 9, 2007.

${ }^{4}$ Nogee, A., Deyette, J., and Clemmer, S. "The Projected Impacts of a National Renewable Portfolio Standard." The Electricity Journal; Vol. 20, Issue 4, May 2007; p. 34.

${ }^{5}$ Database of State Incentives for Renewable Energy, New Jersey Incentives for Renewable Energy and Energy Efficiency, Renewable Portfolio Standard, June 11, 2007. www.dsire.org

${ }^{6}$ Holt, E.; Wiser, R. The Treatment of Renewable Energy Certificates, Emissions Allowances, and Green Power Programs in State Renewable Portfolio Standards. LBNL-62574. Berkeley, CA: Lawrence

Berkeley National Laboratory, April 2007.

${ }^{7}$ Komor, P. Renewable Energy Policy, (Lincoln, NE: iUniverse, 2004) 167. DSIRE database http://www.dsireusa.org/library/includes/incentive2.cfm?Incentive_Code=ME01R\&state=ME\&CurrentPag $\mathrm{eID}=1 \& \mathrm{RE}=1 \& \mathrm{EE}=1 . \mathrm{html}$. Accessed August 6, 2007.

8 "Existing/New REC Capacity Report." ERCOT online, http://www.texasrenewables.com/publicReports/rpt5.asp.html. Accessed August 5, 2007.

${ }^{9}$ Holt, E.; Bird, L. Emerging Markets for Renewable Energy Certificates: Opportunities and Challenge. NREL/TP-620-37388. Golden, CO: National Renewable Energy Laboratory, January 2005.

${ }^{10}$ Holt, E.; Wiser, R. The Treatment of Renewable Energy Certificates, Emissions Allowances, and Green Power Programs in State Renewable Portfolio Standards. LBNL-62574. Berkeley, CA: Lawrence Berkeley National Laboratory, April 2007.

${ }^{11}$ Bird, L. Holt, E. and G. Carroll, "Implications of Carbon Regulation for Green Power Markets," National Renewable Energy Laboratory, Technical Report 640-41076, April 2007, 24.

${ }^{12}$ See Bonneville Environmental Foundation Website https://www.greentagsusa.org/GreenTags/index.cfm (accessed December 13, 2006).

${ }^{13}$ Bird, L.; Swezey, B. Green Power Marketing in the United States: A Status Report ( ${ }^{\text {th }}$ Edition). NREL/TP-640-40904. Golden, CO: National Renewable Energy Laboratory, November 2006.

${ }^{14}$ Bird, L.; Swezey, B. Green Power Marketing in the United States: A Status Report ( $9^{\text {th }}$ Edition).

NREL/TP-640-40904. Golden, CO: National Renewable Energy Laboratory, November 2006., p. 5

15 "Green Power Partnership." U.S. Environmental Protection Agency online.

http://www.epa.gov/greenpower/partners/top25.html. April 9, 2007.

${ }^{16}$ Collison, B. EPA Green Power Partnership, Email, August 18, 2006.

${ }^{17}$ See EPA Green Power Partnership Website http://www.epa.gov/greenpower/partners/gpp partners.htm, accessed August 6, 2007.

${ }^{18}$ U.S. EPA. Comments of the U.S. Environmental Protection Agency. Project No. 31852, Rulemaking

Relating to Renewable Energy Amendments, Public Utility Commission of Texas.

${ }^{19}$ Holt, E.; Wiser, R. The Treatment of Renewable Energy Certificates, Emissions Allowances, and Green Power Programs in State Renewable Portfolio Standards. LBNL-62574. Berkeley, CA: Lawrence Berkeley National Laboratory, April 2007

${ }^{20}$ Holt, E.; Bird, L. Emerging Markets for Renewable Energy Certificates: Opportunities and Challenge. NREL/TP-620-37388. Golden, CO: National Renewable Energy Laboratory, January 2005, 16.

${ }^{21}$ Holt, E.; Wiser, R. The Treatment of Renewable Energy Certificates, Emissions Allowances, and Green Power Programs in State Renewable Portfolio Standards. LBNL-62574. Berkeley, CA: Lawrence

Berkeley National Laboratory, ,April 2007.

${ }^{22}$ Holt, E.; Wiser, R. The Treatment of Renewable Energy Certificates, Emissions Allowances, and Green Power Programs in State Renewable Portfolio Standards. LBNL-62574. Berkeley, CA: Lawrence Berkeley National Laboratory, April 2007.

${ }^{23}$ Cory, K.; Swezey, B. "Renewable Portfolio Standards in the States: Balancing Goals and Rules." The Electricity Journal; Vol. 20, Issue 4, May 2007; p. 24. 
${ }^{24}$ Hurlbut, D. "A Look behind the Texas Renewable Portfolio Standard - A Case Study," Golden, CO: National Renewable Energy Laboratory report (forthcoming).

${ }^{25 ،}$ Texas Legislature Repeals Problematic RPS Language,” U.S. EPA Green Power Network, News, June 1, 2007, http://www.eere.energy.gov/greenpower/news/news_template.shtml?id=1264.

${ }^{26}$ Holt, E.; Wiser, R. The Treatment of Renewable Energy Certificates, Emissions Allowances, and Green Power Programs in State Renewable Portfolio Standards. LBNL-62574. Berkeley, CA: Lawrence Berkeley National Laboratory, April 2007.

${ }^{27}$ Holt, E.; Wiser, R. The Treatment of Renewable Energy Certificates, Emissions Allowances, and Green Power Programs in State Renewable Portfolio Standards. LBNL-62574. Berkeley, CA: Lawrence Berkeley National Laboratory, ,April 2007.

${ }^{28}$ Ed Holt and Ryan Wiser, "The Treatment of Renewable Energy Certificates, Emissions Allowances, and Green Power Programs in State Renewable Portfolio Standards," Lawrence Berkeley National Laboratory, LBNL-62574, April 2007, pg. 26.

${ }^{29}$ Arizona Public Utilities Commission Docket number RE-OOOOOC-05-0030, November 14, 2006.

${ }^{30}$ Allen, R. Vermont Department of Public Service, Personal Communication, July 3, 2007.

${ }^{31}$ Holt, E.; Wiser, R. The Treatment of Renewable Energy Certificates, Emissions Allowances, and Green Power Programs in State Renewable Portfolio Standards. LBNL-62574. Berkeley, CA: Lawrence

Berkeley National Laboratory, ,April 2007; p. 22.

32 "EPA Green Power Partnership Requirements." U.S. Environmental Protection Agency online, http://www.epa.gov/greenpower/pdf/gpp_partnership_reqs.pdf.

33 "Green-e National Standard." Green-e, Center for Resource Solutions online. http://www.greene.org/getcert_re_stan.shtml. Updated January 6, 2006.

34 "Green-e Verification Report 2005." Green-e, Center for Resource Solutions online. http://www.greene.org/getcert_re_veri.shtml.

35 "Uniform National Standard for Ecopower ${ }^{\mathrm{SM}}$ Renewable Energy Certificates," Environmental Resources Trust, June 2006, p.12.

${ }^{36}$ John Kunz, Director of Ecopower ${ }^{\text {SM }}$ program, Environmental Resources Trust, Personal Communication, June 20, 2007.

37 "Uniform National Standard for Ecopower ${ }^{\mathrm{SM}}$ Renewable Energy Certificates," Environmental Resources Trust, June 2006, p. 11.

${ }^{38}$ Lori Bird and Blair Swezey, "Green Power Marketing in the United States: A Status Report $\left(9^{\text {th }}\right.$ Edition)," National Renewable Energy Laboratory, Technical Report 640-40904, November 2006, 24.

${ }^{39}$ L. Bird, B. Parsons, T. Gagliano, et. al, "Policies and Market Factors Driving Wind Power Development in the United States," National Renewable Energy Laboratory, Technical Report 620-34599, July 2003, 44.

${ }^{40}$ Anthony, Jeff. American Wind Energy Association and former program manager of We Energies green pricing program, email September 19, 2007

${ }^{41}$ Paul Copleman, Public Relations Manager, Community Energy, Personal Communication, June 27, 2007.

${ }^{42}$ Karlynn Cory and Blair Swezey, "Renewable Portfolio Standards in the States: Balancing Goals and Rules," Electricity Journal, Vol. 20, Issue 4, May 2007, 23.

${ }^{43}$ Information on RPS rules for geographic eligibility are summarized in "Table C-1: State Minimum Renewable Electricity Requirements (as of April 2007)" developed by the Union of Concerned Scientists http://www.ucsusa.org/clean_energy/clean_energy_policies/clean-energy-policies-and-proposals.html, accessed October 5, 2007.

${ }^{44}$ Database of State Incentives for Renewable Energy, www.dsire.org

${ }^{45}$ Barbara Farhar, "Willingness to Pay for Electricity from Renewable Resources: A Review of Utility Market Research," National Renewable Energy Laboratory, NREL/TP 550.26148, July 1999, 5.

${ }^{46}$ See TVA Green Power Switch program http://www.tva.gov/greenpowerswitch/partners/index.htm, accessed August 28, 2007.

${ }^{47}$ Barrett Stambler, "Supplying Green Power in Compliance and Voluntary Markets," PPM Energy, Presentation at the Tenth National Green Power Marketing Conference, Austin, Texas, October 26, 2005.

48 "Options: Connecticut Clean Energy Options," http://www.ctcleanenergyoptions.com/options.htm.

${ }^{49}$ Keri Enright, SmartPower, Personal Communication, July, 3, 2007. 


\footnotetext{
${ }^{50}$ Howard B. Bernstein, Massachusetts RPS Program Manager, Massachusetts Division of Energy Resources, Personal Communication, July 2, 2007.

51 "Massachusetts Incentives for Renewable Energy: Renewable Portfolio Standard," Database of State Incentives for Renewable Energy, June 11, 2007, www.dsire.org.

${ }^{52}$ Ryan Wiser, Christopher Namovicz, Mark Gielecki, and Robert Smith, "The Experience with Renewable Portfolio Standards in the United States," The Electricity Journal, Vol 20, Issue 4, May 2007, 16.

${ }^{53}$ State of Connecticut, Public Act 06-74: An Act Concerning Biomass, http://www.cga.ct.gov/2006/ACT/Pa/pdf/2006PA-00074-R00SB-00212-PA.pdf

${ }^{54}$ Ed Holt and Lori Bird, "Emerging Markets for Renewable Energy Certificates: Opportunities and Challenge," National Renewable Energy Laboratory, Technical Report 620-37388, January 2005, 25.

${ }^{55}$ Andrew Kolchins and Andrew Stainthorpe, "Renewable Portfolio Standards Gain in Popularity," Natural Gas Electricity, Vol 23, Number 7, February 2007, 4.

${ }^{56}$ Albany Times-Union, "Price Rise Blowing In The Wind; Demand For Green Energy Causes Shortage; State's Renewable Energy Program Consumes Supply,” Larry Rulison, September 13, 2007.

${ }^{57}$ Lori Bird and Blair Swezey, "Green Power Marketing in the United States: A Status Report $\left(9^{\text {th }}\right.$ Edition)," National Renewable Energy Laboratory, Technical Report 640-40904, November 2006, 22.

${ }^{58}$ Swezey, B., J. Aabakken, and L. Bird. "A Preliminary Examination of the Supply and Demand Balance for Renewable Electricity," Prepared by the National Renewable Energy Laboratory for the U.S.

Environmental Protection Agency, Green Power Partnership, October 2007.

${ }^{59}$ Paul Komor, "Wind Power in Colorado: Small Steps to Sustainability," published in Sustainable Energy and the States edited by Dianne Rahm (Jefferson, NC: McFarland \& Company, Inc, 2006) 133.

${ }^{60}$ Anthony, Jeff. American Wind Energy Association and former program manager of We Energies green pricing program, email September 19, 2007.

${ }^{61}$ Graph based on data provided to NREL by utilities. Not all utilities report renewable energy sales data to NREL, so the graph does not represent all utility sales. However, most large programs are included.
} 


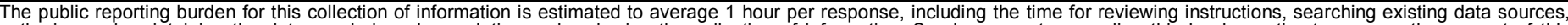

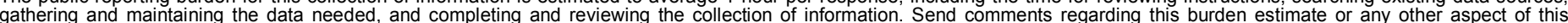

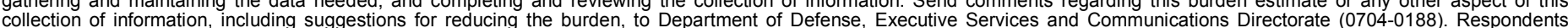

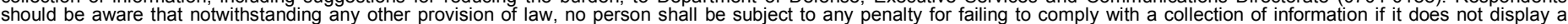

should be aware that notwithstanding

PLEASE DO NOT RETURN YOUR FORM TO THE ABOVE ORGANIZATION.

\begin{tabular}{l|l|l|l} 
1. REPORT DATE $(D D-M M-Y Y Y Y)$ & 2. REPORT TYPE & 3. DATES COVERED (FrOm - TO)
\end{tabular}

October 2007

Technical Report

4. TITLE AND SUBTITLE

Interaction of Compliance and Voluntary Renewable Energy

Markets

5a. CONTRACT NUMBER

DE-AC36-99-G010337

5b. GRANT NUMBER

5c. PROGRAM ELEMENT NUMBER

6. AUTHOR(S)

Lori Bird and Elizabeth Lokey

5d. PROJECT NUMBER

NREL/TP-670-42096

5e. TASK NUMBER

IGST.7330

5f. WORK UNIT NUMBER
7. PERFORMING ORGANIZATION NAME(S) AND ADDRESS(ES)

National Renewable Energy Laboratory

1617 Cole Blvd.

Golden, CO 80401-3393
8. PERFORMING ORGANIZATION REPORT NUMBER

NREL/TP-670-42096

9. SPONSORING/MONITORING AGENCY NAME(S) AND ADDRESS(ES)

10. SPONSOR/MONITOR'S ACRONYM(S) NREL

11. SPONSORING/MONITORING AGENCY REPORT NUMBER

12. DISTRIBUTION AVAILABILITY STATEMENT

National Technical Information Service

U.S. Department of Commerce

5285 Port Royal Road

Springfield, VA 22161

\section{SUPPLEMENTARY NOTES}

\section{ABSTRACT (Maximum 200 Words)}

In recent years, both compliance and voluntary markets have emerged to help support the development of renewable energy resources. Both of these markets are growing rapidly and today about half of U.S. states have RPS policies in place, with a number of these policies adopted in the last several years. In addition, many states have recently increased the stringency of their RPS policies. This paper examines key market interaction issues between compliance and voluntary renewable energy markets. It provides an overview of both the compliance and voluntary markets, addressing each market's history, purpose, size, scope, and benefits while addressing issues, including double counting.

15. SUBJECT TERMS

NREL; green power market; REC; renewable energy; compliance market; voluntary market; green pricing programs; RPS; state poicies; Lori Bird; Elizabeth Lokey

\begin{tabular}{l}
\hline 16. SECURITY CLASSIFICATION OF: \\
\begin{tabular}{|l|l|l|}
\hline a. REPORT & b. ABSTRACT & c. THIS PAGE \\
Unclassified & Unclassified & Unclassified \\
& & \\
\hline
\end{tabular}
\end{tabular}

\begin{tabular}{l|l} 
17. LIMITATION & 18. \\
OF ABSTRACT & OF PAGES \\
UL & \\
\end{tabular}

19a. NAME OF RESPONSIBLE PERSON

19b. TELEPHONE NUMBER (Include area code) 